\title{
NO donors and NO delivery methods for controlling biofilms in chronic lung infections
}

\author{
Yu-Ming Cai ${ }^{1}$ (D) $\cdot$ Ying-Dan Zhang ${ }^{2} \cdot$ Liang Yang $^{2}$ \\ Received: 22 January 2021 / Revised: 23 March 2021 / Accepted: 5 April 2021 / Published online: 3 May 2021 \\ (C) The Author(s) 2021
}

\begin{abstract}
Nitric oxide (NO), the highly reactive radical gas, provides an attractive strategy in the control of microbial infections. NO not only exhibits bactericidal effect at high concentrations but also prevents bacterial attachment and disperses biofilms at low, nontoxic concentrations, rendering bacteria less tolerant to antibiotic treatment. The endogenously generated NO by airway epithelium in healthy populations significantly contributes to the eradication of invading pathogens. However, this pathway is often compromised in patients suffering from chronic lung infections where biofilms dominate. Thus, exogenous supplementation of NO is suggested to improve the therapeutic outcomes of these infectious diseases. Compared to previous reviews focusing on the mechanism of NO-mediated biofilm inhibition, this review explores the applications of NO for inhibiting biofilms in chronic lung infections. It discusses how abnormal levels of NO in the airways contribute to chronic infections in cystic fibrosis (CF), chronic obstructive pulmonary disease (COPD), and primary ciliary dyskinesia (PCD) patients and why exogenous NO can be a promising antibiofilm strategy in clinical settings, as well as current and potential in vivo NO delivery methods.
\end{abstract}

\section{Key points}

- The relationship between abnormal NO levels and biofilm development in lungs

- The antibiofilm property of $N O$ and current applications in lungs

- Potential NO delivery methods and research directions in the future

Keywords Nitric oxide $\cdot$ Biofilm $\cdot$ Chronic lung infection $\cdot$ Pseudomonas aeruginosa

\section{Introduction}

The past century witnessed the successful fight against many acute bacterial infections in lungs with the discovery of different antibiotics, such as life-threatening pneumonia which can now be cured with proper antimicrobial therapy. However, slower-progressing chronic lung infections are now affecting the life quality of millions of people (Bjarnsholt 2013; Quaderi and Hurst 2018; Kelly 2017).

Yu-Ming Cai

yc2m18@soton.ac.uk

Liang Yang

yangl@sustech.edu.cn

1 Institute for Life Sciences, University of Southampton, Southampton SO17 1BJ, UK

2 School of Medicine, Southern University of Science and Technology, Shenzhen 518000, China
These infections are often associated with bacterial biofilms, a growth mode where multiple bacteria stick together and form a consortium. Compared to the free-floating planktonic state, this growth mode provides encased individual cells much higher tolerance to antibiotics, leading to chronic symptoms and therapy failures. With the slow progress in finding new antibiotics, antibiofilm agents can serve as an adjunctive therapy in chronic lung infections, enhancing the susceptibility of bacterial cells towards current antibiotics and increasing life expectancy (Li and Lee 2017).

One antibiofilm agent that attracted much attention is nitric oxide (NO). NO is endogenously produced by many types of cells in the airway and regulates different cell behaviours. Particularly, NO plays a crucial part in innate immunity against a small inoculum of inhaled bacteria, where a high concentration (above micromolar) of NO generates reactive nitrogen oxide species (RNOS) by the reaction with oxygen or superoxide. RNOS exert bactericidal effects via damaging bacterial DNA, inhibiting enzyme functions and inducing 
lipid peroxidation (Schairer et al. 2012; Darling and Evans 2003; Sivaloganathan and Brynildsen 2020). In the past 15 years, NO was also found to inhibit bacterial biofilms in different settings at much lower, nontoxic concentrations (piconanomolar) (Barraud et al. 2015). As such, the dual functions of $\mathrm{NO}$ can both be used to fight against lung infections. However, in CF, COPD and PCD patients, pathogens cannot be cleared out by abnormal levels of endogenous NO, resulting in chronic infections. Exogenous NO successfully reduced biofilms and potentiated the efficacy of conventional antibiotics in CF patients (Howlin et al. 2017), suggesting it may also be a promising antibiofilm agent in other lung diseases. Here, we summarize current knowledge of the abnormal NO levels in CF, PCD and COPD patients, the efficacy of NO on biofilms formed by chronic lung infection-related pathogens, and the existing devices for exogenous NO applications. The aim is to trigger more investigations into the compromised NO pathways in different patients and improve the efficiency of NO application in chronically infected airways.

\section{Chronic infections in different pulmonary diseases}

Chronic lung infections can develop in patients suffering from certain diseases or conditions that cause deficiency in their innate immunity. For example, a compromised first line barrier of lung epithelium cells are often found in chronically infected lungs. The epithelium of bronchial wall is covered by cilia, on top of which residents the mucus (Boyton and Openshaw 2002). The outer layer of mucus is a viscous gel phase comprising a mixture of water, glycoproteins, immunoglobulins, lipids, and electrolytes, whilst the inner layer, directly in contact with cilia, is a fluid or sol phase (López and Martinson 2017). Mucus is continuously swept back up through the lungs by the movement of cilia (ciliary beating), referred to as mucociliary transport (López and Martinson 2017). This mechanism allows inhaled bacteria that are trapped in the mucus layer to be cleared out and ensures that pathogens do not directly contact with the epithelial cells or reach the alveolar cavities (Fliegauf et al. 2013), However, a deficient mucociliary transport is found in cystic fibrosis (CF), chronic obstructive pulmonary disease (COPD) and primary ciliary dyskinesia (PCD) patients. PCD is an autosomal recessive genetic disorder causing defects in ciliary biogenesis, structure, and function (Wijers et al. 2017; Horani et al. 2016). Such malfunctioning cilia are unable to move properly and propel mucus, leading to a progressive accumulation of mucus and the failure of mucociliary transport. In contrast, CF is caused by mutations in the cystic fibrosis transmembrane conductance regulator (CFTR) gene, which is translated into proteins function as chloride channels in surface airway epithelial cells and the cells of the submucosal glands. The lack/ dysfunction of this channel leads to insufficient chloride transport followed by reduced water secretion. The failure to maintain proper salt-water balance results in abnormal periciliary fluid depth and the production of highly viscous mucus that remain tethered to gland ducts, interfering with ciliary movement and contributing to the failure in mucociliary transport (Chmiel and Davis 2003; Hoegger et al. 2014). Smoking and exposure to noxious gases and particles are the leading causes of COPD, which can reduce both the number and length of cilia, enlarge the submucosal glands, and increase the number of goblet cells, leading to mucus hypersecretion that further interfere with ciliary motion (Simet et al. 2010; Rogers 2005).

Despite the different aetiologies, chronic bacterial infection is the main reason for decreased life quality and shortened life expectancy of these patients. Some bacteria involved in these infections can survive treatments that are predicted to eradicate them, where conventional antibiotics lose their efficacies. These infections may persist lifelong in some patients. The therapy failure leads to a vicious circle - damaged lungs fail to resist new infections, whilst new infections further damage lung tissue. The most prevalently found pathogens in CF lungs range from Haemophilus influenzae and Staphylococcus aureus as early colonisers in children, to Pseudomonas aeruginosa and Burkholderia cepaciancomplex frequently isolated from adults (Surette 2014). $H$. influenza, Streptococcus pneumonia, P. aeruginosa, Moraxella catarrhalis, Haemophilus parainfluenzae and $S$. aureus are frequently found in stable COPD patients (Beasley et al. 2012). For PCD patients, nontypeable $H$. influenzae (NTHi) is the most commonly isolated species, followed by P. aeruginosa, S. aureus, S. pneumoniae, and M. catarrhalis (Alanin et al. 2015). Why can't these patients clear the infection?

\section{Biofilms in chronically infected lungs}

\section{$P$. aeruginosa aggregates in CF respiratory tracts}

Aggregated biofilms are now recognised as the cause of many chronic infections. Specific to chronic lung diseases, the initial observation and the very first micrograph of a slimy biofilm in CF sputum was published in 1977 (Høiby 2017, 1977). Many later clinical examinations repeatedly confirmed the existence of biofilms/aggregates in CF sputa and the lumen of CF lungs (Worlitzsch et al. 2002; Bjarnsholt et al. 2009; Bjarnsholt et al. 2013) (Fig. 1). Compared to single celled bacteria freely floating in aqueous environments, which are more formally named as "planktonic cells", aggregates or biofilms are bacteria physically stuck together and encased in the self-produced polymeric matrix containing proteins, DNA and polysaccharides (Flemming and Wingender 2010). The protective shield and united lifestyle grant the embedded single cells much higher 
a

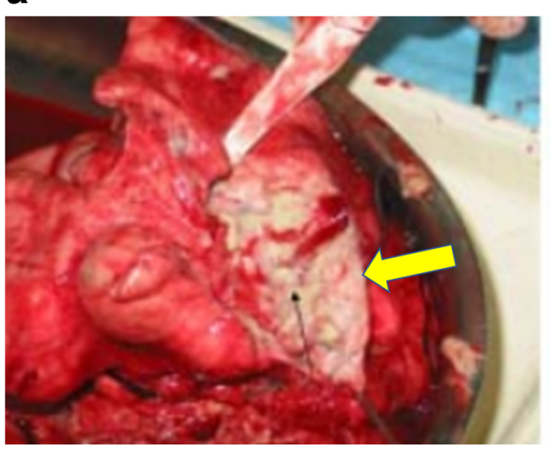

c

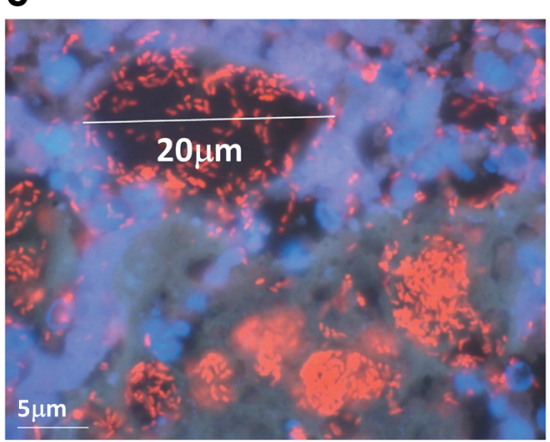

Fig. 1 a Green mucus (yellow arrow) is filling the major airways of a newly explanted CF lung (Bjarnsholt et al. 2009). b Thin section of an obstructed CF bronchus. Aggregated biofilms are not attached to epithelial surface (black arrow) but are embedded within intraluminal material (white arrows). Scale bar $=100 \mu \mathrm{m}$ (Worlitzsch et al. 2002). c Intraluminal $P$. aeruginosa aggregates surrounded by PMNs stained with PNA FISH and DAPI (Bjarnsholt et al. 2009). d NTHi forms massive aggregates

tolerance to innate host defences (Leid 2009). Neutrophils that settle onto aggregates are unable to migrate away from the point of contact, and aggregates in mucus are frequently founded to be surrounded by dead or dying neutrophils. They are unable to penetrate but are instead killed by the pathogens (Downey et al. 2009). Consequently, biofilms that escaped the attack from innate immunity are persistently established in vivo. With the prevalence of $\mathrm{CF}$ (more than 70,000 worldwide with $\sim 1000$ new cases diagnosed per year) and the dominant role of $P$. aeruginosa in the later stage ( $>80 \%$ of $\mathrm{CF}$ adults are entangled with $P$. aeruginosa chronic infection), $P$. aeruginosa biofilm in CF patients inevitably became the most extensively chronic lung infection model.

Invading, planktonic $P$. aeruginosa cells first adhere reversibly to the gel phase of the viscous mucus layer in $\mathrm{CF}$ patients using flagella and pili, followed by cell division and the formation of small clusters as early biofilms/aggregates (Høiby 2002). The dehydrated, concentrated mucus plays a crucial role in the formation of macrocolonies in $\mathrm{CF}$ airways - an in vitro comparison between normal (2.5\% solid) and CF-like (8\% solid) mucus showed that with the same initial inoculum and end point $\mathrm{CFU}$, biofilms were only detected in CF-like mucus (Matsui et al. 2006) (Fig. 2a).

\section{b}

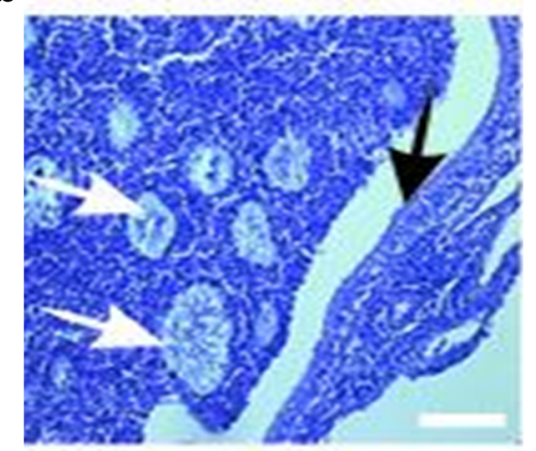

d
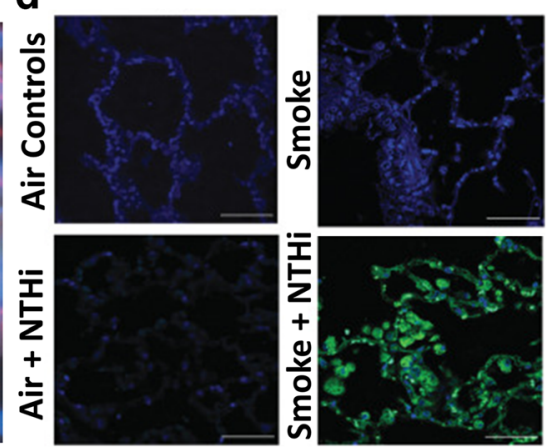

within the lungs of a COPD ferret after infection and smoke exposure, whilst the lungs exposed to air display only few punctate NTHi. Nuclei were stained with DAPI (blue), and bacteria were stained with anti-NTHi polyclonal antibodies conjugated to Alexa 488 (green). Scale bar $=50 \mu \mathrm{m}$ (Hunt et al. 2020). Permissions to reuse images were obtained from journals and/or Copyright Clearance Centre.

Aggregates formed in the thick mucus layer may be promoted by a mechanism called "depletion aggregation" (Secor et al. 2018), which was postulated to be mediated by entropic forces between uncharged/like-charged polymers and bacteria. The thick CF mucus layer contains abundant polymers such as mucin, DNA, and F-actin (all negatively charged), as well as bacteria particles. In such a mixture, polymers cannot reach the surface of bacteria by a distance less than the size of its own radius. Each bacterial cell is therefore surrounded by a "depletion zone". When two bacteria cells come closer, the depletion zones overlap, constraining the presence of polymers in between. The polymer concentration between cells is therefore essentially 0 , whilst the osmotic pressure generated by different concentrations of polymers across the cells can physically hold cells together. This spontaneous aggregation reduces the total depletion zones and produces more space for polymer movement, hence maximizing the entropy of the system following the second law of thermodynamics (Fig. 2b). As such, it is hypothesized that in the presence of abundant polymers, bacteria can quickly aggregate through this passive physical method without the positive involvement of bacterial activities (Dorken et al. 2012; Secor et al. 2018). At this initial stage, $P$. aeruginosa still continues its nonmucoid phenotype 

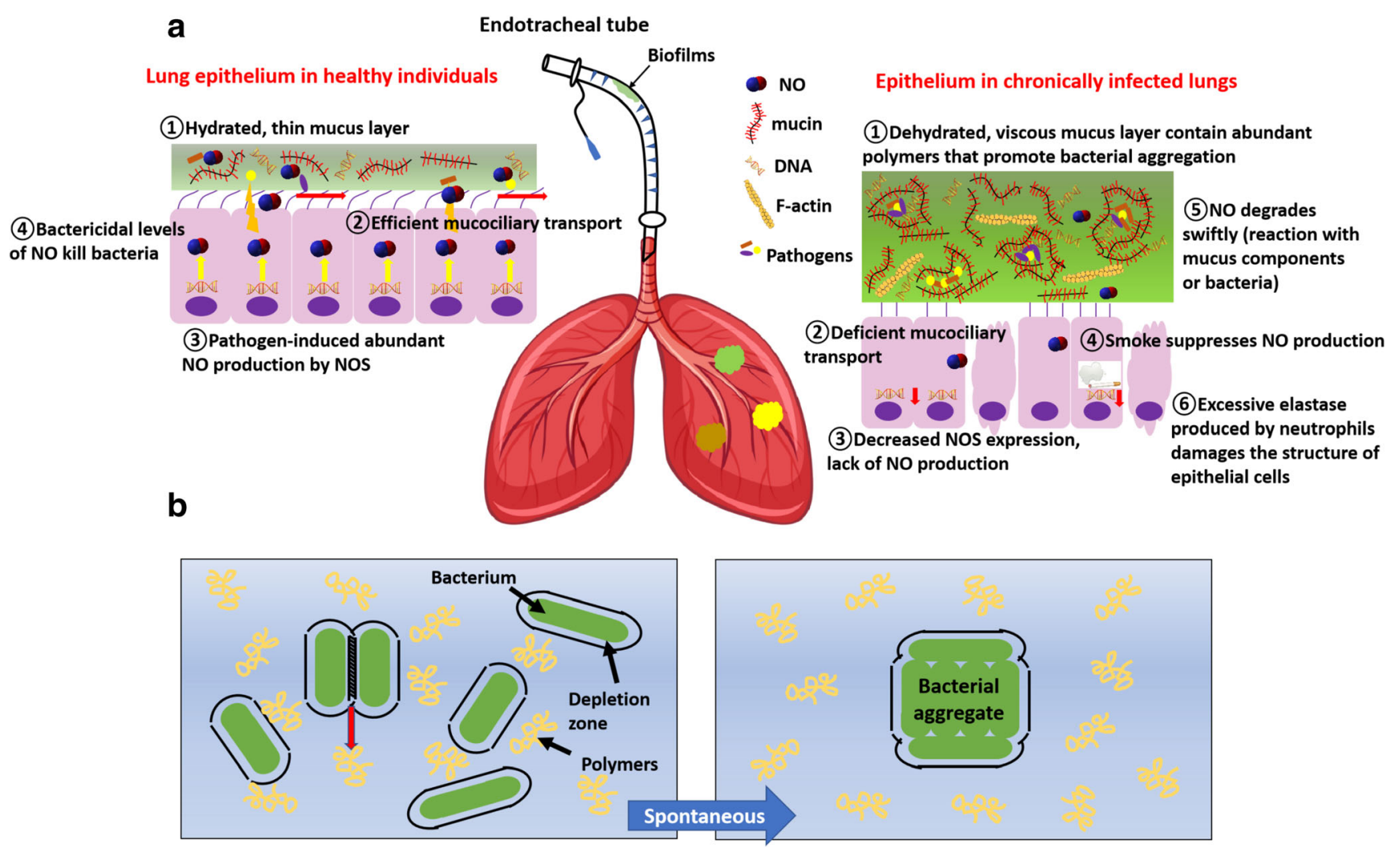

Fig. 2 a Schematic diagram of biofilms/aggregates in chronically infected lungs and possible mechanisms of how abnormal levels of NO are associated with chronic lung infections. b Schematic diagram of depletion aggregation. Bacteria (green spherocylinders); polymers (yellow twisted lines); and depletion zones (dashed lines around the bacteria). When two bacterial cells come closer, polymers in between are squeezed into the solution (red arrow). Such spontaneous aggregation minimizes the depletion zones occupied by bacteria and maximizes the entropy of the system (figure adapted from Dorken et al. 2012). The icons of lung, DNA, and cigarette were obtained from vectors available from Vecteezy.com
(Chmiel and Davis 2003). However, P. aeruginosa that survived the phagocytosis may start benefiting from its end products. For instance, oxygen radicals produced by polymorphonuclear leucocytes (PMNs) as a result of an inflammatory response induces mutations in surviving $P$. aeruginosa, such as in gene muсA (Høiby 2002). Such adaptation leads to excessive alginate production, and this adhesive substance can promote bacterial aggregation, offering stronger protection against both host immune defence and antibiotic delivery. On the other hand, the remaining bacteria stimulate repeated and excessive inflammatory responses, especially the progressive accumulation of neutrophils, which in turn results in overproduction of elastase (Laval et al. 2016). An excessive amount of elastase can degrade a range of cell surface receptors on lymphocytes, neutrophils and dendritic cells that are important for pathogen recognition and digestion (Gifford and Chalmers 2014) and also destructs lung cell tissues causing structural damage that further cripples the clearance process (Chmiel and Davis 2003). Altogether, the thick mucus layer, the in vivo bacterial pathoadaptation, and tissue damage all contribute to the long-term bacterial residence and the development of aggregated biofilms.
Another hallmark of biofilms is the high tolerance to antibiotics provided by this lifestyle besides the intrinsic or acquired resistance, resulting in the chronic pathology in CF patients despite the routine applications of antibiotics. Traditionally, the terms "tolerance" and "resistance" were used interchangeably in many biofilm-related articles. Here in this review, these two terms are distinguished based on their different mechanisms. Resistance is due to intrinsic or acquired genotypes that allows bacteria to survive antibiotic treatments even at planktonic states, which is usually characterised as increased minimum inhibitory concentration values. In contrast, tolerance in biofilms is due to phenotypic changes offered by the formation of biofilms, where cells survive high concentrations of antibiotics only if embedded in biofilms. If cells in biofilms are reverted to planktonic state, they are sensitive to antibiotics (For more details please see review articles from Stewart 2015 and Ciofu and TolkerNielsen 2019). Apart from the different responses to antibiotics offered by growth modes, how biofilms are grown may also significantly affect the efficacy of antibiotics. Clinical examinations observed that bacterial aggregates found in vivo are generally much smaller in size compared to 
surface-attached biofilms grown in laboratory, suggesting a different physiological character under the pressure of host response, ROS, and nutrient limitation (Bjarnsholt 2013). For example, aggregates embedded in the mucus plug are surrounded by PMN cells which consume a large proportion of oxygen, resulting in a lack of access to oxygen for $P$. aeruginosa cells (Kolpen et al. 2014). Aggregates are therefore grown in anaerobic conditions, leading to different metabolism and antibiotic tolerance mechanisms compared to biofilms grown in classic flow-cell systems or microtiter plates. As such, in vitro determination of antibiotic dosage may not accurately reflect the requirement for biofilm elimination in patients. The repeated usage of some antibiotics in patients that are not sufficient to eradicate biofilms may present a selective stress that favour the mutations related to antibiotic resistance, and even the component of CF sputum can cause an accumulation of mutations in the las $R$ gene that increase the tolerance to $\beta$-lactam antibiotics (Marvig et al. 2013; Clark et al. 2018; Azimi et al. 2020). Hence, both physiological tolerance and hereditary genetic mutations offered by the biofilm mode of growth make it almost impossible to eradicate bacterial aggregates settled down in the mucus layer, even with aggressive combinational antibiotic treatments (Soren et al. 2019).

\section{Biofilms/aggregates in the respiratory tract of PCD and COPD patients need further investigation}

Compared to extensively studied chronic infections in $\mathrm{CF}$, biofilms in PCD and COPD patients with chronic bacterial infection and massive mucus production appeared to attract much less attention, despite a wealth of publications generally claimed that the formation of biofilms contribute greatly to the difficulties in the treatment of chronic lung infections. For instance, it was reported that bacterial evolution in PCD and CF patients follows a similar pattern and the biofilm formation ability of $P$. aeruginosa clinical isolates from PCD sputa was tested in vitro (Sommer et al. 2016), but no micrograph was available to confirm the aggregates in sputum samples. $H$. influenzae is the most frequent microorganism isolated from a range of PCD patients (Alanin et al. 2015), yet it was only confirmed in vitro that $H$. influenzae cells are more likely to form aggregates on the PCD epithelial cells than healthy control (Walker et al. 2017). Biofilm growth mode has long been implicated in COPD despite the lack of direct evidence, and this hypothesis was only very recently supported by the detection of $H$. influenzae multicellular aggregates within the airway lumen of COPD ferret (Hunt et al. 2020). Models of chronic lung infection including the implication of microbiota and biofilms have been set up, yet many more investigations are required to consolidate the biofilm growth mode in respiratory tracts of different patients. Assuming that multicellular biofilms can be prevalently found in all these patients, many questions still await to be answered for better treatment strategies. For example, the dominant species found in different patients varies; are all aggregates residing in mucus layers or some are attached to the epithelium? Is there any difference in the size and amount of aggregates observed in different type of patients, and are they correlated to the severity of diseases? How do these in vivo/ex vivo aggregates respond to antibiotics or other treatments?

\section{Biofilm-related infections during mechanical ventilation}

Another special type of biofilms in lung infection occurs during invasive mechanical ventilation, which has been frequently used in very severe acute exacerbation COPD patients. Despite being a life-saving procedure for critically ill patients, intubation with endotracheal tubes (ET tubes) provides perfect landing sites for bacterial adhesion and biofilm formation on both the inner luminal and outer surface (Li et al. 2015; Cairns et al. 2011). The colonisation of microorganisms and the formation of biofilms on ET tubes can be rapid, within hours after insertion (Vandecandelaere et al. 2012), and by the end of 10 days almost all the ET tubes are covered by biofilms. A close link was observed between the microbial flora of ET tube biofilms and the microorganisms involved in the onset of ventilator-associated pneumonia (VAP), including frequently identified multidrug-resistant ESKAPE pathogens (Vandecandelaere and Coenye 2015). Biofilms on ET tubes are therefore heavily responsible for VAPs, resulting in higher mortality rates and much longer ICU- and hospital-lengths of stay (Diaconu et al. 2018). More importantly, biofilms on ET tubes also show great tolerance under the challenge of antibiotics like those grown on plastic plates in vitro, requiring novel combinational therapeutic strategies for an efficient biofilm treatment in VAP patients (Gordon Sahuquillo et al. 2015).

\section{Abnormal levels of NO are associated with chronic lung infections}

Apart from the mucociliary transport, lung epithelium cells are also primary sources of NO (Lane et al. 2004). Endogenously produced NO in the airways is evidenced by its appearance in the exhaled breath. NO is synthesized from L-arginine by NO synthase (NOS) with three isoforms-endothelial NOS (eNOS), neuronal NOS (nNOS), and inducible NOS (iNOS). Both eNOS and nNOS are constitutively expressed and can generate picomolar levels of NO in pulmonary endothelial cells and nonadrenergic, noncholinergic inhibitory 
neurons, respectively (Xu et al. 2006). The iNOS is continuously expressed under basal airway conditions, and can be induced by inflammatory stimuli during bacterial infection to produce bactericidal levels of NO (Xu et al. 2006; Guo et al. 1995). The total production of NO from these NOSs can be reflected by fractional exhaled nitric oxide (FENO) quantifying the level of nitric oxide gas in the breath (Miskoff et al. 2019; Duong-Quy 2019).

However, much lower FENO levels are frequently found in CF patients (Elphick et al. 2001; Korten et al. 2018; Grasemann et al. 1997; Keen et al. 2010; Thomas et al. 2000). Bronchial epithelium from CF lungs showed less immunohistochemistry stain for iNOS compared to controls, and further in situ hybridization also showed less iNOS mRNA in CF epithelium than in controls (Meng et al. 1998). When a differentiated human bronchial epithelial cell line derived from CF patient is transfected with human iNOS cDNA, reduced $P$. aeruginosa adherence and enhanced killing of internalised bacterial cells were observed (Darling and Evans 2003). Also, genetic variations in the baseline nos 1 (nNOS) lead to an altered NO production (Texereau et al. 2004; Grasemann et al. 2002; Grasemann et al. 2000), and CF patients harbouring nos1 genotypes are much more susceptible to $P$. aeruginosa colonisation (Grasemann et al. 2002). These all suggest that in CF patients, the low level of NO may play an important role in the higher susceptibility towards pathogens.

Epithelium is not the only NO resource during an inflammation in the airway, and different immune cells can also produce NO in response to pathogenic stimuli. It was found that PMN cells in freshly expectorated sputum samples from CF patients with chronic $P$. aeruginosa infection can actively produce NO (Kolpen et al. 2014). However, NO is an unstable free radical, and once released into the aqueous or gel phase of the thick mucus layer comprising a vast number of biological components, it might degrade quickly before reaching the bacterial cells. This postulation was supported by some findings where high concentrations of the stable NO metabolites nitrate and nitrite were detected in CF sputum, despite the lowered FENO (Grasemann et al. 1998; Jones et al. 2000). These stable end products of $\mathrm{NO}$ accumulated in mucus may in return favour the growth of $P$. aeruginosa in anoxic environment through denitrification process, promoting the chronic infection (Zumft 1997).

A marked reduction in nasal $\mathrm{NO}(\mathrm{nNO})$ and FENO was repeatedly found in PCD patients compared to healthy controls (Walker et al. 2012; Walker et al. 2013; Lucas and Walker 2013; Shapiro et al. 2017; Zhang et al. 2019a; Horváth et al. 2003). Despite NTHi being the leading pathogen in PCD, several hypothesis were raised to explain the reduced NO in PCD similar to in $\mathrm{CF}$, including increased breakdown of NO trapped in paranasal sinuses, and lowered expression/function loss of NOS. However, with conflicting data from different publications, the underlying mechanisms still remain unclear (Walker et al. 2012). An early study showed that NO metabolites were not decreased in PCD exhaled breath condensate, suggesting the existence of $\mathrm{NO}$ in the secretion (Csoma et al. 2003). A later study compared the expression of NOS amongst children with PCD and with secondary ciliary dyskinesia (SCD, comparably infected and inflamed control group who did not have a congenital defect of ciliary function) (Pifferi et al. 2011). The expression of iNOS was significantly lower in children with PCD compared SCD group, and a positive relationship between iNOS gene expression and nNO levels was demonstrated, implying an impaired expression of iNOS may count for lowered NO output in PCD patients. A lack of substrate L-arginine may also contribute to the lack of NO production, as administration of L-arginine increased nasal and exhaled nitric oxide levels in PCD patients (Grasemann et al. 1999; Loukides et al. 1998). Despite the lack of direct evidence, such lowered NO in PCD patients may further compromise the nonspecific defences against pathogens in the airway on top of deficient ciliary movement, contributing to recurrent sinopulmonary infection. A particularly interesting study was conducted by a healthy researcher with no history of sinus problem, where he developed sinus infection after the nasal application of NOS inhibitors in his right nostril with a marked reduction of $\mathrm{NO}$, whilst the untreated left nostril remained unaffected (Lundberg 2005). Although this experiment was conducted in nasal, the results may support the general notion that NO plays an important role in primary host defence in the upper airways.

The relationship between NO and COPD is much more complicated with the involvement of cigarette smoke, which may interfere with NO pathway in addition to the inflammation process. As COPD patients may have different history of smoking, accordingly, reported exhaled NO levels in COPD were conflictual depending on the subjects and measurement approaches (Corradi et al. 1999; Ansarin et al. 2001; Brindicci et al. 2005; Clini et al. 1998; Rutgers et al. 1999; Maziak et al. 1998). A recent meta-analysis based on a wealth of literature concluded that FENO levels in COPD patients are higher than healthy controls (Lu et al. 2018). This can be supported by previous studies showing that the expression levels of iNOS and nNOS were higher in COPD patients than nonsmokers and smokers with normal lung function (Jiang et al. 2015; Maestrelli et al. 2003; Brindicci et al. 2010). Apart from comparing COPD and healthy individuals, one consensus appears that current smokers exhale less NO than ex-smokers (Corradi et al. 1999; Clini et al. 1998; Malerba et al. 2014; Hynes et al. 2015; Högman et al. 2019). The contribution of cigarette smoke to a lowered FENO in current smoker was postulated to be a downregulation of NOS, or that the oxidants in smoke may damage bronchial epithelial cells and suppress the production of NO (Malerba et al. 2014), or an increased NO consumption in smokers' airways (Malinovschi et al. 2006). 
Solid evidence for the effect of smoke on the function of NOS and NO production in vivo are yet to be achieved. Interestingly, cigarette smoke extract was shown to inhibit the NOS activity in lung epithelial cells and pulmonary artery endothelial cells in vitro (Su et al. 1998; Hoyt et al. 2003), but when mice were exposed to cigarette smoke for either a short time (2-24 h) or 8 months, increased iNOS was found (Wright et al. 2002; Seimetz et al. 2011). Thus, much needs to be investigated for a clearer picture of NO pathway, NO production and consumption, as well as the relationship between NO and the pathogenesis in COPD patients.

Due to the controversial NO output and NOS expression levels in different type of patients, it is impossible to conclude at this stage that chronic infection can be primarily attributed to a deficiency in NO production. However, suffice to say, at least the amounts of functional NO in the respiratory tracts of all these patients are not enough to eliminate the invading pathogens, which subsequently allows for their long-term residence.

\section{Nitric oxide as an antibiofilm agent}

\section{Low-dose NO disperses biofilms; high-dose NO eradi- cates biofilms}

It was well-documented that NO plays dual functions in humans - at low concentrations, it serves as an intracellular signal regulating a range of cell behaviours; at high concentrations, it exhibits cytotoxicity against tumours and can promote apoptosis. Similar dose-dependent scenarios also apply to bacteria- besides the bactericidal effect at above micromolar scales, NO can prevent the formation of biofilms or disperse established ones as a signalling molecule when administrated at low concentrations (pico-nanomolar). Dispersal is the natural, final stage of biofilm life cycle, where cells are released from mature biofilms for reestablishment at a more favourable niche (Kaplan 2010). Under clinical settings, exogenously added, low concentrations of $\mathrm{NO}$ can also trigger this procedure - they reduce the CFU and total biomass of biofilms remaining on the surface by reverting sessile biofilm cells back to free-swimming planktonic state, without posing a lethal effect to bacterial cells within the biofilms. Such action increases the susceptibility of cells encased in biofilm towards other treatments, thus enhancing therapeutic outcomes. For example, by using a traditional NO donor, sodium nitroprusside (SNP), Barraud et al. showed that nontoxic dose of NO (500 nanomolar) can trigger the dispersal of mature $P$. aeruginosa biofilms and prevent initial attachment (Barraud et al. 2006). Further studies elucidated that NO modulates $P$. aeruginosa biofilm through regulating a secondary messenger, bis-(3-5)-cyclic dimeric GMP (c-di-GMP), that can be found in most bacterial species (Barraud et al. 2009a;
Römling et al. 2013). c-di-GMP is synthesised by a group of enzymes named diguanylate cyclase (DGC), and is hydrolysed by another group of enzymes named phosphodiesterase (PDE). High concentrations of intracellular c-di-GMP promote the switch from planktonic growth modes to biofilm formation (Römling et al. 2013). NO decreases intracellular c-di-GMP levels in $P$. aeruginosa via directly or indirectly stimulating several PDEs, such as NbdA, DipA and RbdA (Barraud et al. 2009a; Morgan et al. 2006; Petrova and Sauer 2012a; Petrova and Sauer 2012b; Li et al. 2013) (See reviews by Cutruzzolà and Frankenberg-Dinkel 2016; Williams and Boon 2019 for detailed molecular mechanisms). Low-dose NO was also proven to prevent or disperse biofilms formed by many different species, although different concentrations and donors were required (Arora et al. 2015; Thompson et al. 2019; Islam et al. 2020). Whilst NO-c-diGMP pathway was found in Legionella pneumophila, Shewanella oneidensis, and Shewanella woodyi (Carlson et al. 2010; Plate and Marletta 2012; Liu et al. 2012; Fischer et al. 2019), some Gram-positive strains such as S. aureus do not contain c-di-GMP related protein domains but can still disperse upon NO challenge, suggesting an alternative signalling cascade is involved and yet to be determined. In contrast, NO released at higher concentrations (micro-millimolar) can eradicate $P$. aeruginosa biofilms by both disrupting the physical structures of biofilms and exhibiting toxicity towards interior cells. NO was shown to decrease the viscoelastic moduli and weaken the mechanical properties of biofilms matrix, possibly through polysaccharide depolymerization and DNA structural damage (Reighard et al. 2015; Rouillard et al. 2020a; Yang et al. 2018; Duan and Kasper 2011; Burney et al. 1999). Structural disruption in biofilms increases the exposure of individual cells towards bactericidal levels of NO, leading to eradication. As such, both low and high dosage of NO treatment can reduce biofilms via different mechanisms. Despite the lack of solid evidence of in vivo biofilms formed by other leading pathogens frequently isolated from chronic lung infection patients besides $P$. aeruginosa, in vitro biofilms formed by these species showed different responses to NO treatment (Table 1). Whilst NO was confirmed to reduce biofilms formed by $P$. aeruginosa, $S$. aureus, B. cepacian, and M. catarrhalis, NTHi and S. pneumoniae appeared unaffected at concentrations that are effective against other species. Whether this resistance comes from some intrinsic mechanisms of these two species, or it is more of the nonoptimised experimental procedures or NO resources remains unknown. Deeper studies into the effect of NO on different species, especially clinical isolates, with more appropriate in vitro models that recapitulate the in vivo environment may potentially facilitate future clinical administration. So far, the only successful clinical trial of low dose NO for biofilm inhibition was conducted in CF patients targeting P. aeruginosa aggregates (Howlin et al. 2017), and whether 
Table 1 The efficacy of NO on the biofilms formed by leading pathogens in different diseases with chronic lung infections

\begin{tabular}{|c|c|c|c|}
\hline Species & NO resources & Biofilm reduction? & Biofilm culture method \\
\hline P. aeruginosa & 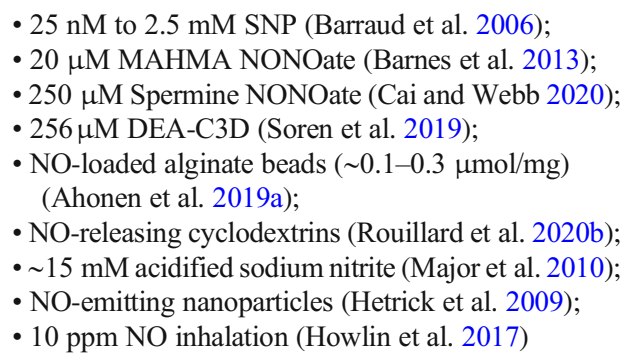 & Yes & $\begin{array}{l}\text { Plate (M9 minimal medium, MH } \\
\text { medium); } \\
\text { Artificial sputum medium; } \\
\text { CF patients }\end{array}$ \\
\hline S. aureus & $\begin{array}{l}\text { - Dressings producing }>200 \text { ppmv gaseous NO } \\
\text { (Sulemankhil et al. 2012); } \\
\text { - } 60 \mathrm{mg} / \mathrm{ml} \text { isosorbide mononitrate (ISMN) (Hasan } \\
\text { et al. 2018) or ISMN encapsulated in liposome } \\
\text { (Jardeleza et al. 2014); } \\
\text { - } 125-1000 \mu \mathrm{M} \text { DETA NONOate (Jardeleza et al. } \\
\text { 2011); } \\
\text { - NO-loaded alginate beads ( 0.1-0.3 } \mu \mathrm{mol} / \mathrm{mg}) \\
\text { (Ahonen et al. 2019a); } \\
\cdot>15 \mathrm{mM} \text { acidified sodium nitrite (Major et al. } 2010) \text {; } \\
\cdot \text { NO-emitting nanoparticles (Hetrick et al. } 2009)\end{array}$ & Yes & $\begin{array}{l}\text { Plate (tryptic soy broth, } \\
\text { MH medium, cerebrospinal fluid } \\
\text { (CSF) broth); artificial sputum } \\
\text { medium }\end{array}$ \\
\hline NTHi & $\begin{array}{l}50 \mu \mathrm{M} \text { cephalosporin-3'-diazeniumdiolate } \\
\text { (PYRRO-C3D/DEACP) (Walker et al. 2017) }\end{array}$ & $\begin{array}{l}\text { No, but potentiates the efficacy of } \\
\text { antibiotic }\end{array}$ & $\begin{array}{l}\text { Plate (BHI medium); coculture } \\
\text { with primary respiratory ciliated } \\
\text { epithelial cells }\end{array}$ \\
\hline B. cepacia & $\begin{array}{l}\cdot \text { NO-loaded alginate beads (Ahonen et al. 2019a); } \\
\cdot>15 \text { mM acidified sodium nitrite (Major et al. 2010) }\end{array}$ & Yes & $\begin{array}{l}\text { Plate (MH medium); } \\
\text { Artificial sputum medium }\end{array}$ \\
\hline S. pneumoniae & $100 \mu \mathrm{M}$ and $1 \mathrm{mM}$ SNP (Allan et al. 2016) & $\begin{array}{l}\text { Yes, } 1 \mathrm{mM} \text { SNP reduced the viability of } \\
\text { cells, and } 100 \mu \mathrm{M} \text { potentiates the } \\
\text { efficacy of antibiotic }\end{array}$ & Plate (1:5 diluted BHI broth) \\
\hline M. catarrhalis & $1 \mathrm{mM}$ nitrite (Mocca et al. 2015) & $\begin{array}{l}\text { Yes, NO radical derived from nitrite } \\
\text { reduction kills cells in biofilms }\end{array}$ & $\begin{array}{l}\text { Coculture with human bronchial } \\
\text { epithelial cell }\end{array}$ \\
\hline
\end{tabular}

it can disaggregate other biofilms in other types of patients awaits to be evaluated.

\section{NO potentiates the efficacy of conventional antimicrobials}

As the biofilm growth mode offers bacteria significant recalcitrance to antimicrobials, reversing the embedded cells back to planktonic state by NO can increase their susceptibility towards treatments. Previous studies showed that $P$. aeruginosa biofilms formed on catheters can tolerate $>100 \mu \mathrm{l} / \mathrm{ml}$ gentamicin, colistin, chloramphenicol, ciprofloxacin, and tetracycline. However, when combined with NO, $>3-\log$ reduction of viable biofilms cells was observed when antibiotics were administrated only at $10 \mu \mathrm{l} / \mathrm{ml}$ (Ren et al. 2016). Nanoparticles that simultaneously release both gentamicin and NO can decrease the viability of $P$. aeruginosa biofilms by $90 \%$ at concentrations of $10-50 \mu \mathrm{M}$, which was much more efficient than stand-alone applications of either agent (Nguyen et al. 2016). Low dose NO significantly enhanced the efficacy of tobramycin, colistin and tobramycin+ ceftazidime against in vitro biofilms formed by CF-PA isolates or ex vivo aggregates in CF sputa, suggesting a great clinical potential of this combinational therapy (Soren et al. 2019; Howlin et al. 2017). The performance of several other antimicrobials in $P$. aeruginosa biofilms, including SDS, $\mathrm{H}_{2} \mathrm{O}_{2}$ and human $\beta$-defensin 2, was also increased in the presence of NO (Barraud et al. 2006; Ren et al. 2016). The remaining CFU of $S$. aureus biofilms was reduced by 3-log when challenged with $\mathrm{NO}+$ ciprofloxacin compared to the antibiotic treatment alone (Hasan et al. 2018). Using a NTHi biofilm and PCD ciliated epithelial cells coculture model, Walker et al. reported that the susceptibility of NTHi biofilms towards azithromycin was boosted by NO, despite the same NO dosage per se failed to reduce the CFU of NTHi biofilms (Walker et al. 2017). Apart from reducing the tolerance in biofilms, NO can also improve the susceptibility of planktonic, multidrugresistant pathogens towards different antimicrobials. For instance, NO-releasing chitosan oligosaccharides pretreatment resulted in a 2 to $4-\log$ reduction in the viability of planktonic $P$. aeruginosa, MRSA and $B$. cepacia, as well as biofilms formed by multidrug-resistant $P$. aeruginosa isolates, 
compared to tobramycin exposure alone (Rouillard et al. 2020c). A prominent synergistic effect of NO and silver sulfadiazine was observed for many pathogens, including P. aeruginosa and MRSA (Privett et al. 2010). A combination of NO and superoxide resulted in a 1000-fold reduction of CFU count in planktonic B. cepacia compared to either component alone (Smith et al. 1999). Hence, exogenous NO presents a promising adjunctive therapeutic strategy in chronic lung infection management, either by enhancing the bactericidal effect of antimicrobials against individual cells entering the airway before biofilm formation, or reducing the tolerance of established biofilms/aggregates.

\section{NO delivery in vivo}

Different devices for NO delivery may significantly influence the clinical outcome. The administration of NO in patients is not a new concept - the earliest medical application of NO dates to 1879 , where nitroglycerin was found able to relieve angina (Murrell 1879). The increasing discoveries of the biological activities of NO triggered a growing interest in chemist/pharmacist for the searching of new NO releasing agents and novel NO delivery strategies, as some traditional donors were proven to be toxic or carcinogenic. Furthermore, due to the short half-life and cytotoxicity effect of high-dose NO, inappropriate administration time, uncontrolled NO release or over dosage may lead to deleterious side effects and injuries (Asmawi et al. 1999; Weinberger et al. 1999; Murakami et al. 1997; Korde Choudhari et al. 2013). As such, the development of novel NO-releasing strategies for better delivery and less side effects, still remains a challenge. In the context of chronic lung infection, the involvement of pathogens adds another layer of complication - what is the optimal dosage that can remove the biofilms without triggering undue side effects? Which NO donor possesses an appropriate degradation half-life that allows released $\mathrm{NO}$ to be available in the vicinity of biofilms in vivo? Apparently, there is still a long way to go, given the fact that listed studies in Table 1 were mostly conducted in vitro. In this section, we summarize some traditionally and recently developed NO delivery methods (Fig. 3), hoping to stimulate more advanced research for NO-mediated bacterial inhibition in chronic lung infection.

\section{Inhalation of gaseous NO}

Inhaled nitric oxide gas was approved by FDA in 1999 for the treatment of hypoxic infants (Nelin and Potenziano 2019). Some commercial devices such as INOMAX® and Genosyl have been developed and approved by FDA for NO inhalation, which have facilitated the administration. Previous studies showed that inhalation of NO helped clear lung infections in rats infected by $P$. aeruginosa and reduced the bacterial load by 1.7-2-log (Webert et al. 2000; Jean et al. 2002). In $K$. pneumoniae infected mice, inhaling NO at lower oxygen concentration also resulted in a 5 to 10 -fold reduction of CFU in BALF and lung tissues (Sun et al. 2006). Similar bactericidal effects were also observed in CF patients, where case studies showed that intermittent administrations of $160 \mathrm{ppm}$ NO significantly reduced CFU of $P$. aeruginosa, $S$. aureus, and $B$. multivorans in $\mathrm{CF}$ patients that are resistant to multiple antibiotics (Deppisch et al. 2016; Bartley et al. 2020). As such, inhalation of NO may improve the therapy of chronic lung infections in CF patients, particularly for those suffering from MDR pathogens. Although the above reports showed that such high dosages of NO were well-tolerated in tested patients, they may bring along toxic side effects to others. For instance, after high dosages $(\geq 80 \mathrm{ppm})$ of $\mathrm{NO}$ inhalation, methemoglobinemia can be observed, and the high concentrations of toxic nitrogen dioxide generated from spontaneous oxidation result in direct injury to the alveolar epithelial cells and may even cause pulmonary oedema (Davidson et al. 1998; Kido et al. 2017). In addition, the toxic reactive nitrogen intermediates such as peroxynitrite generated under conditions of high-NO flux may induce structural alterations in DNA and cell damage, interfere with the activity of lung surfactants and increase surface tension (Hallman and Bry 1996). As the metabolic fate and systemic effects of inhaled NO can be largely affected by airway chemistry and environment, the administration of high dose NO needs careful evaluation in different patients. Whilst the applications of such high dosage were mainly due to the bactericidal effect of NO, the first clinical trial with low-dose NO inhalation (5-10 ppm) combined with standard antibiotics (ceftazidime and tobramycin) also reduced the number of $P$. aeruginosa biofilm aggregates by 3.5-log in 12 CF patients (Howlin et al. 2017). These results indicated that low dose NO may be used as adjunctive therapy for CF-related biofilm infections, especially when highdosage NO inhalation causes severe toxicological effects.

Inhalation of NO (lower than $80 \mathrm{ppm}$ ) has also been applied in COPD patients for reducing pulmonary vascular resistance (Ashutosh et al. 2000; Hajian et al. 2016; Yoshida et al. 1997). However, the relationship between inhaled NO and bacterial load in COPD patients have not been investigated yet. As the existence of biofilm is yet to be confirmed in these patients, no study was carried out to evaluate if such lower dose of NO in COPD patients can inhibit biofilm aggregates. Future studies on NO applications in COPD patients with pulmonary hypertension may consider including sputum culture data for determining a possible change in bacterial load. Inhalation of NO has not been a favoured device for NO augmentation in PCD patients so far. It is therefore not yet known if it is appropriate to administrate NO in PCD patients through inhalation, and if suitable can it also reduce bacterial load and inhibit biofilms. Further investigations are needed to address these questions. 


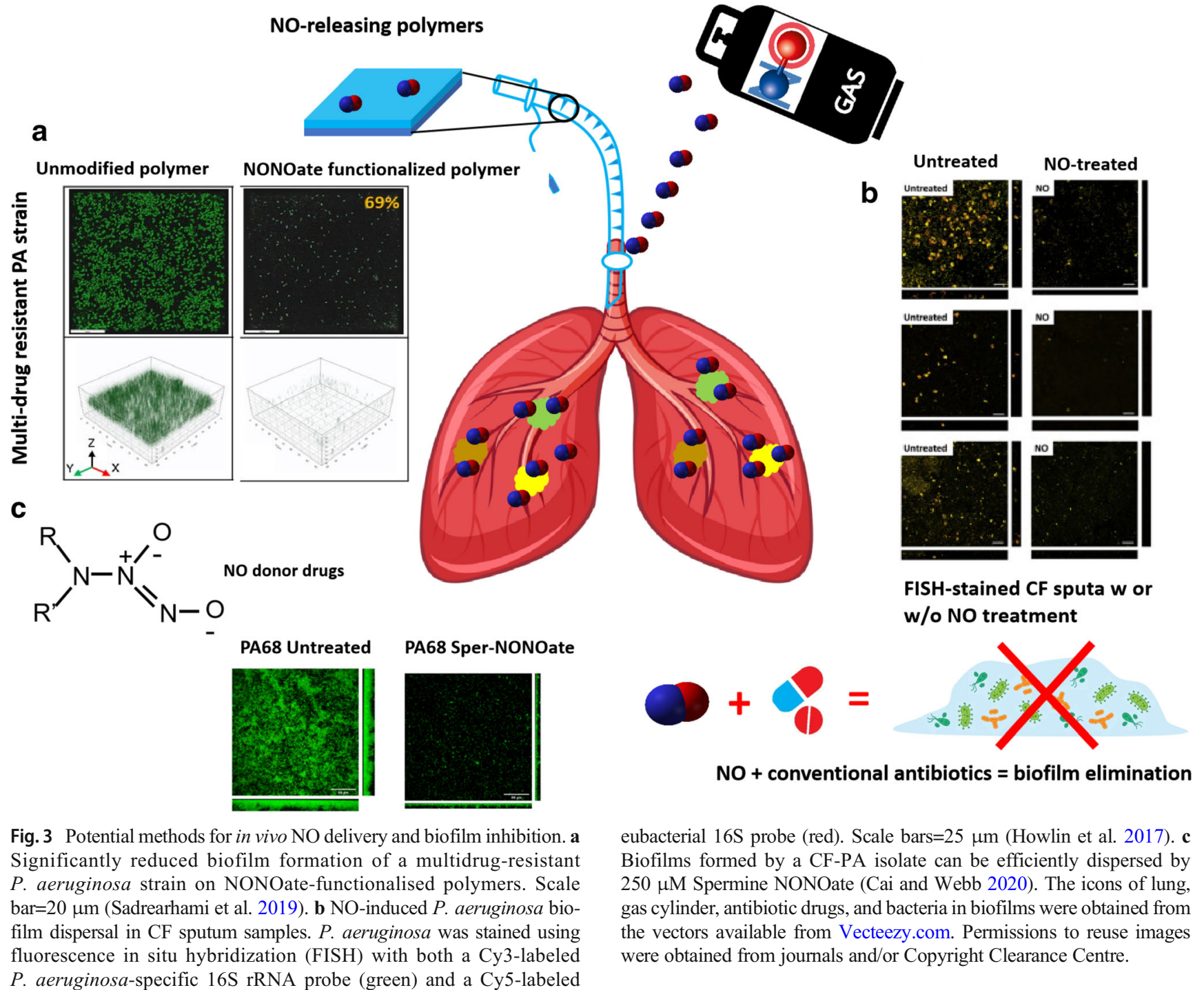

\section{NO-releasing compounds (NO donors)}

Some classic NO donors proven by FDA such as SNP, nitroglycerin (NTG), and isosorbide dinitrate (ISDN), have long been used in a variety of clinical settings in cardiovascular diseases (Hottinger et al. 2014; den Uil and Brugts 2015; Nyolczas et al. 2018). Yet, some side effects rising from the constant usage of organic nitrates and SNP were observed. For example, a long-term supply of nitroglycerin may cause nitrate tolerance, increase oxidative stress, and induce endothelial dysfunction (Daiber and Münzel 2015; Sydow et al. 2004; Schulz et al. 2002; Hink et al. 2007). This tolerance was observed in almost all organic nitrate compounds, albeit to different extent. Much less tolerance was found in the usage of SNP. However, the decomposition of SNP releases cyanide, and the toxicity as a result of cyanide accumulation concurrent with the nitroprusside administration is well

documented in clinical cases, even when the dosage was lower than recommended (Davies et al. 1975; Chung et al. 2016; Udeh et al. 2015; Rindone and Sloane 1992). Such side effects triggered the particular interest in other two classes of $\mathrm{NO}$ donors, diazeniumdiolates (NONOates) and S-nitrothiols, due to their distinct advantages. NONOates are a series of compounds containing a $\mathrm{X}-[\mathrm{N}(\mathrm{O}) \mathrm{NO}]-$ functional parent nuclear structural unit, where $\mathrm{X}$ represents different amines or polyamines. They can spontaneously decompose to generate up to 2 moles of NO per mole of donors with first order release kinetics under physiological conditions. The half-lives of NONOates at body temperature and $\mathrm{pH}$ largely depend on the chemical structures of amines, which exhibit a wide range that covers different demands. Moreover, after NO release, there is no other metabolites produced except for the original amines (For a more detailed review of NONOates please see Li et al. 
2020). However, such spontaneous systemic release can lead to enormous off-target effects, and it is hard to precisely control the concentrations of $\mathrm{NO}$ at a desired location during real administrations. The unintended NO release or reactions, especially at high concentrations, may cause harmful or even cytotoxic effect in different cell types. The subsequent reactions between decomposition products could also lead to the formation of carcinogenic nitrosamine in vivo (Maragos et al. 1991). As such, the long-term safety of these compounds needs careful confirmation. Most NONOates are still at experimental stage despite the great promise, and there can be big gaps between laboratory and in vivo results (Chen and Zhang 2013).

In contrast, the chemistry of NO release from Snitrosothiols is very complex. This class of compounds (general formula RSNO) contain a nitroso group attached by a single chemical bond to the sulphur atom of a thiol, where $\mathrm{R}$ denotes a cysteine-containing peptide (Patel et al. 2017). SNitrosoglutathione (GSNO) is endogenously produced by many tissue cells in human, whilst both in vitro and in vivo studies suggested that some other S-nitrosothiols are also unlikely to exhibit significant cytotoxicity when used at pharmacologically relevant concentrations (Miller et al. 2000). NO release can be triggered by a variety of factors such as light, heat, metals, other thiols, and different enzymes. Particularly, these compounds can directly transfer $\mathrm{NO}^{+}$species to another thiol via transnitrosation reaction, which may lead to altered enzyme or receptor activity (Singh et al. 1996). Such flexible metabolic pathways will unlikely trigger tolerance after longterm usage (Miller and Megson 2007). On the other hand, however, the stability of RSNOs in vivo is difficult to predict by in vitro experiments. The number of thiol-containing enzymes, the presence of trace metals, as well as the levels of intracellular thiol glutathione, can be influenced by many disease states (Tullett et al. 2001). As RSNOs offer many advantages over the current FDA-approved NO donors, some studies focused on manipulating the chemical properties of $\mathrm{R}$ groups that can increase the stability of existing compounds (for more details please, see reviews by Richardson and Benjamin (2002) and Al-Sa'doni and Ferro (2000)).

Although NONOates and S-nitrosothiols are greatly favoured, some other types of NO donors are still attracting much attention. Some NO donors at experimental stages, investigational stage or approved by FDA that belong to 14 major classes of NO donors are listed in Table 2, along with their status in biofilm-related research. This selection is based on their potential clinical application for biofilms in chronic lung infections. Another common class of NO donors, nitroso compounds, is not included due to their carcinogenic features (Eichholzer and Gutzwiller 1998). Whilst these NO donors offer great potential in future markets, many more investigations are required for their side effects and dosage windows, especially if they are appropriate to be applied in chronic lung infections.

\section{NO donor prodrugs (NO-drug hybrid)}

The side effects of the abovementioned traditional NO donors triggered a novel approach taking the most advantage of $\mathrm{NO}$ whilst minimizing toxicity - attaching a NO-releasing moiety to an existing drug. Different hybrid compounds were produced to offer various drug actions with synergistic effects, which may also reduce side effects of parent compounds and slow down NO release. So far, hybrid drugs with nitrate (nitric-oxide-releasing nonsteroidal antiinflammatory drugs, NO-NSAIDs), Snitrosothiols (nitrosylated $\alpha$-adrenoreceptor antagonists moxisylate ,S-NO-moxisylate; Diclofenac derivatives containing S-nitrosothiols, S-NO-diclofenac), NONOates (NONO-aspirin and NONO-indomethacin) and furoxan (furoxannicorandil) have been developed, showing great clinical potency (Fiorucci et al. 2001; Sáenz De Tejada et al. 1999; Bandarage et al. 2000; Velázquez et al. 2008; Mu et al. 2000). Apart from the applications in cardiovascular and inflammatory diseases, NO donor prodrugs that are linked to antimicrobials or can be specifically activated by bacterial enzymes have attracted much attention from medical microbiologists. For instance, a combination of metronidazole (and its amino analogues) with furoxan and furazan moieties yielded some compounds that exhibited higher antibacterial efficacies against Helicobacter pylori, even for clinical isolates that resist metronidazole (Bertinaria et al. 2003). Considering the spontaneous decomposition of NONOates, Chen et al. synthesized $\beta$ galactosylpyrrolidinyl diazeniumdiolates ( $\beta$-Gal-NONOate), which showed much higher specificity and bactericidal activity towards E. coli engineered to express $\beta$-galactosidase (Chen et al. 2006). However, these compounds did not solve the problem of low specificity against different clinical isolates in the complex in vivo environment. Following the concept of using bacteria-specific enzymes, a prodrug linking a diazeniumdiolate moiety to a $\beta$-lactam analogue cephalosporin, Cephalosporin-3'-diazeniumdiolates (DEACP/C3D/PYRROC3D), was developed (Barraud et al. 2012). This compound remains highly stable in solution and only releases NO upon the activation of bacteria-specific enzyme $\beta$-lactamase. In vitro studies showed that DEACP can effectively inhibit $P$. aeruginosa biofilms, including those formed by clinical isolates, and increased the susceptibility of $P$. aeruginosa and NTHi biofilms against antibiotics (Soren et al. 2019; Barraud et al. 2012; Collins et al. 2017). Furthermore, the effective concentration of DEACP against biofilms exhibits no cytotoxicity when tested on murine fibroblast cells (Barraud et al. 2015), showing great potential for clinical trials. Despite the necessity of further tests in mucus and animal models, this method of drug hybridization based on broad-spectrum, bacteria-specific enzymatic activities and NO donors may significantly increase the specificity of NO delivery towards pathogens surrounded by a myriad of biological targets in chronically infected lungs. 


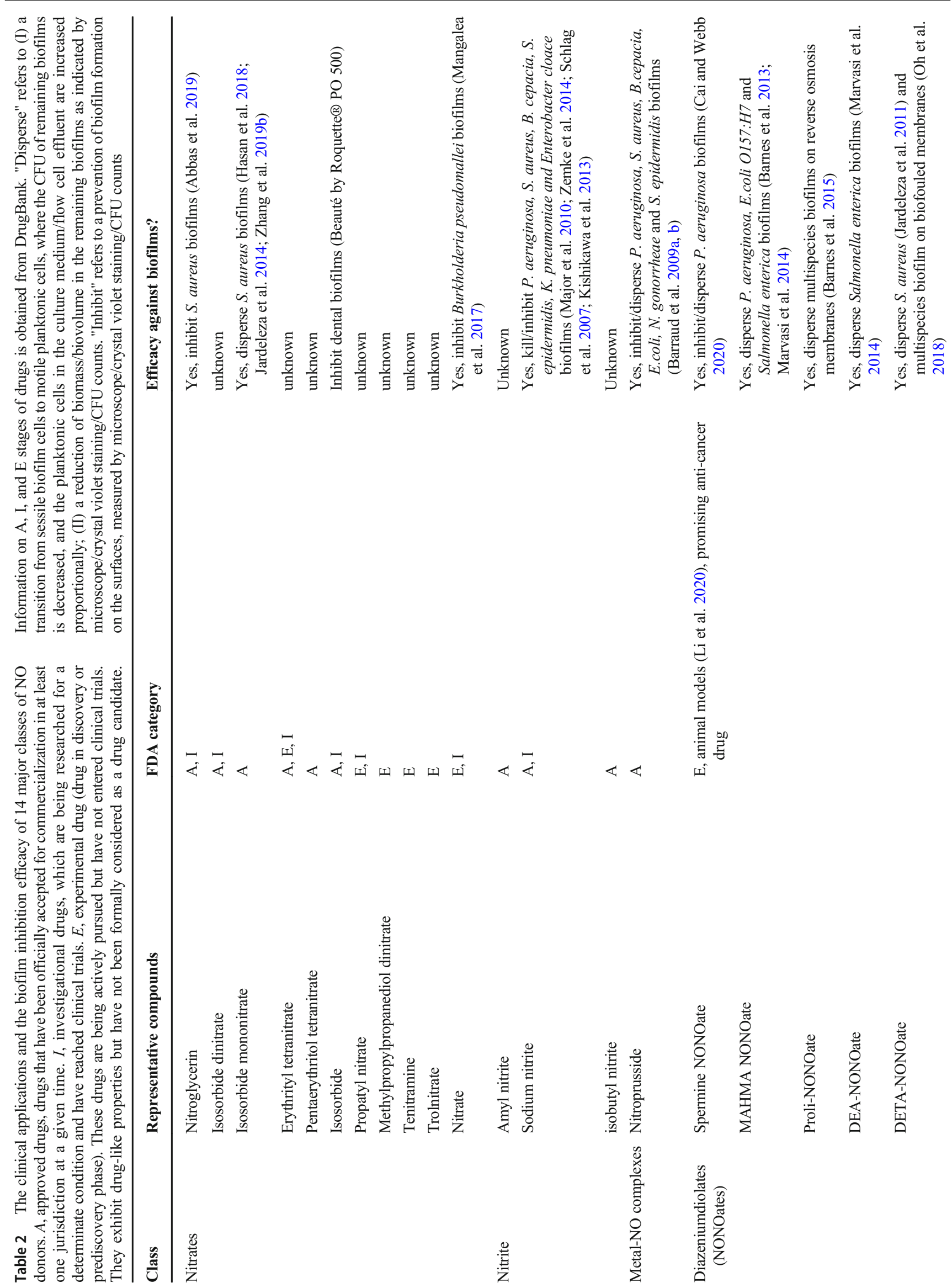




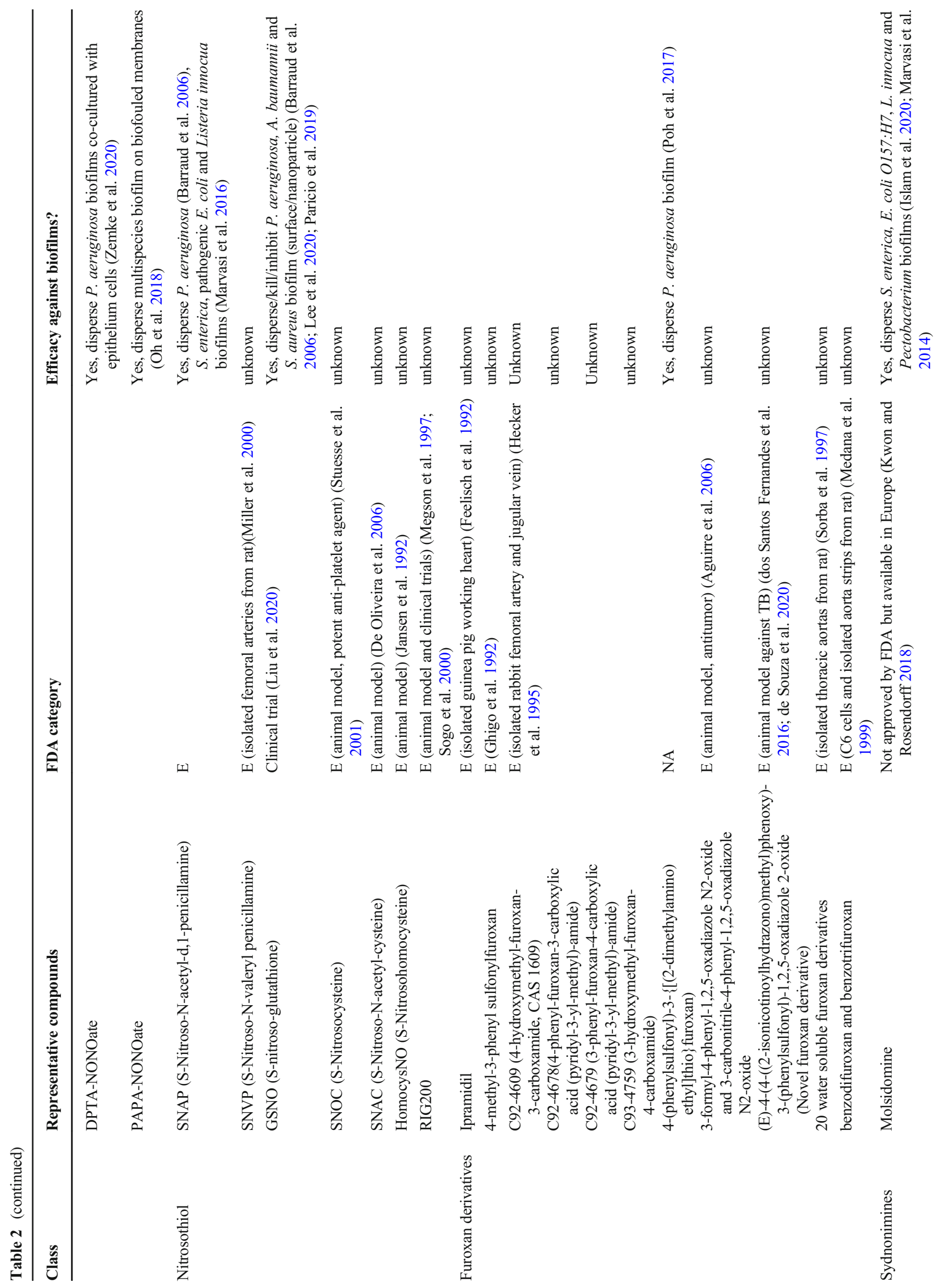




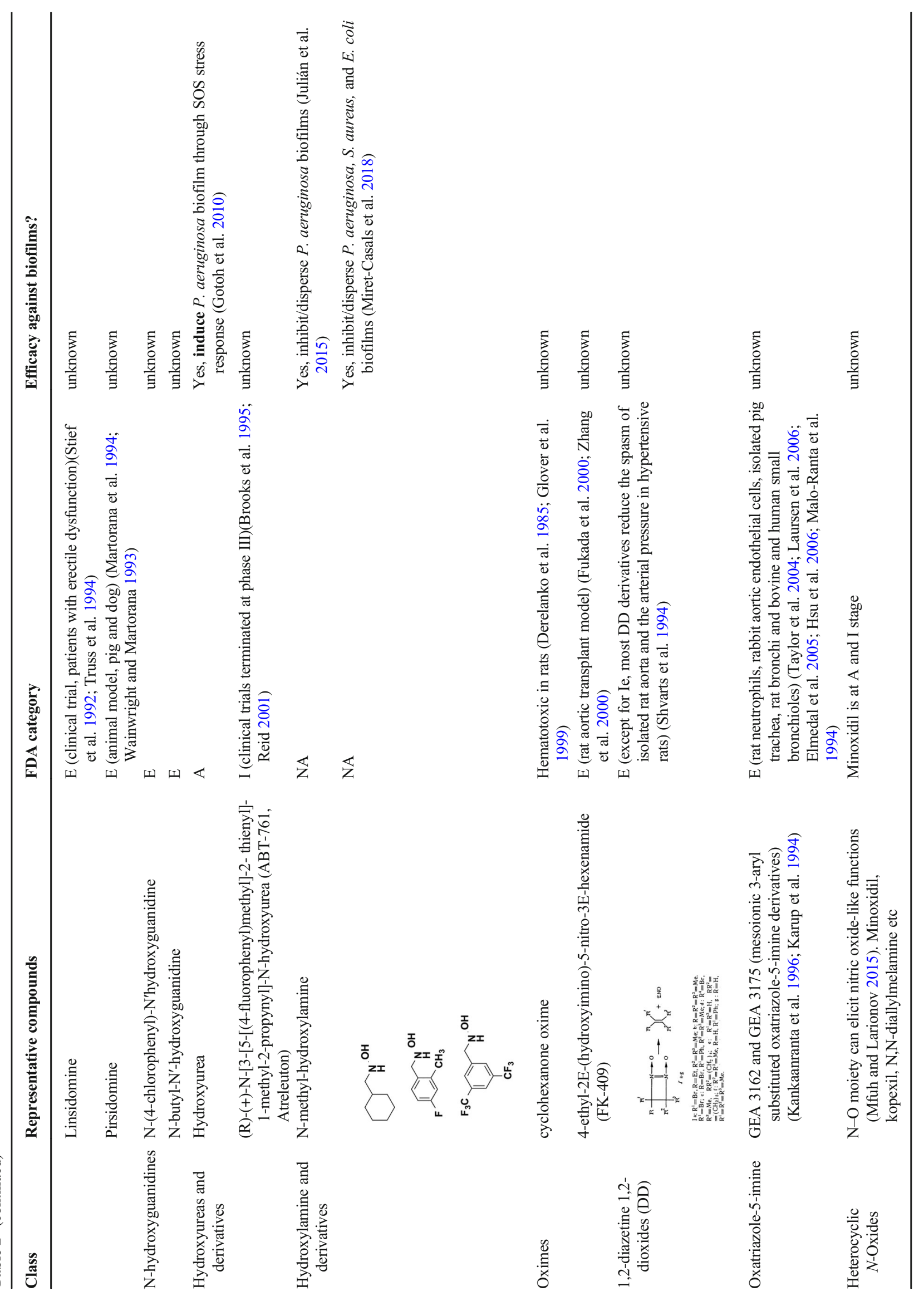




\section{NO-releasing polymeric materials}

Synthetic and hybrid polymers have been used for multiple medical applications. Due to their tunable physical and chemical properties by modifying synthetic precursors and procedures, they can be designed to load many different molecules matching specific requirements (Maitz 2015). Polymers are also proven to be efficient platforms for NO, with excellent NO storage stability and prolonged NO release. Furthermore, they can also be easily loaded with other antimicrobial substances to achieve synergistic effects (Rong et al. 2019; Namivandi-Zangeneh et al. 2018). Numerous NO-releasing polymers have been developed in recent years for antimicrobial and antibiofilm effects, either in the format of small-sized nanoparticles as drug vectors to improve solubility and tissue specificity, or as surface coating for in-dwelling medical devices (Rong et al. 2019). For instance, polyvinyl chloride impregnated with S-nitroso-N-acetylpenicillamine (SNAP) significantly reduced the colonisation of $E$. coli and $S$. aureus, with excellent storage stability and ease in preparation (Feit et al. 2019). A core cross-linked star polymer containing poly(oligoethylene methoxy acrylate) and encapsulated NONOates significantly prevented the formation of $P$. aeruginosa biofilms and can greatly convert established biofilms into planktonic cells at concentrations that are nontoxic to bacteria (Duong et al. 2014b). However, the cytotoxicity of these two types of polymer against human cell lines was not investigated. Metal nanoparticles coated with NOreleasing polymers were also developed, such as AuNP@P(OEGMA)-b-P(VBHA/NO) prepared by grafting NONOate functionalised poly((oligoethyleneglycol methyl ether) methacrylate)-block-poly(vinyl benzyl chloride) onto Au nanoparticles. This polymer/gold hybrid nanoparticle constantly released $\mathrm{NO}$ at a slow rate for 6 days, resulting in an $83 \%$ reduction in the biomass of $P$. aeruginosa biofilms (Duong et al. 2014a). However, when tested against human cell lines, these NO-loaded nanoparticles significantly decreased the viability of both cancer and noncancerous cells. Although the reason behind such cytotoxicity was not evaluated, earlier studies raised the concerns with diazeniumdiolated-based polymers, where NO-donors were found to leach from the polymers and potentially result in the formation of carcinogenic N-nitrosoamines (Annich et al. 2000; Mowery et al. 2000). This leach also suggested the issues with sustained NO release and the stability of the NO donor within this type of polymers, which could limit shelf life or ability to be sterilised. Therefore, covalent attachment of the diazeniumdiolate group to the polymer backbone was deemed as a better approach in the development of new NONOate-conjugated polymers.

Whilst the abovementioned polymers tend to release $\mathrm{NO}$ at a relatively low concentration aiming at inhibiting biofilm formation, polymers storing a large volume of NO may eradicate biofilms with its bactericidal function. A copolymer consisting of cross-linked branched polyethylenimine (bPEI) onto N-carboxy propionyl chitosan sodium bear many secondary amines for NO loading, and an overall release amount of NO at $2.031 \mu \mathrm{mol} / \mathrm{mg}$ yielded prominent antibacterial function against $E$. coli and S. aureus (Ji et al. 2017). Alginate and chitosan are ideal platforms for inhalation applications due to their high solubility, compatibility for nebulization and little toxicity (Lee and Mooney 2012; Ahmad et al. 2005; de Jesús Valle et al. 2008; Hall et al. 2020). Nitric oxide (NO)-releasing alginates with a NO storage of $0.1-0.3 \mu \mathrm{mol} / \mathrm{mg}$ were highly antibacterial against $P$. aeruginosa, B. cepacia and $S$. aureus cultured in artificial sputum medium, resulting in a 5-log reduction in biofilm viability within $24 \mathrm{~h}$ (Ahonen et al. 2019a). NO-releasing chitosan oligosaccharides (COS-EA/NO) significantly reduced the viability of $P$. aeruginos $a$ and $S$. aureus planktonic cells, as well as eradicated P. aeruginosa biofilms (Hall et al. 2020). Both NO-loaded alginate and chitosan exhibited negligible toxicity to human epithelial lung cells A549, and the latter showed much better performance than $\mathrm{NO}$ gas in buffered solutions, mucus, and artificial sputum (Hall et al. 2020; Rouillard et al. 2020a; Ahonen et al. 2018). Although direct inhalation of NO gas has been widely used as aforementioned, the high reactivity and short lifetime of NO in biological media, as well as the necessity in phase transition for diffusion into solutions, can hinder its total efficacy in vivo. In contrast, the similarly inhalable NO-releasing alginate and chitosan release their NO payload directly into the solution and only when in contact, allowing for more targeted and effective treatment. Moreover, as chitosan scaffold is positively charged, it promotes specific target against negatively charged bacteria and biofilm (Hall et al. 2020). Apart from the bactericidal effect of NO, COS-EA/NO was found to decrease the viscoelastic moduli and weaken the mechanical properties of biofilms (Reighard et al. 2015; Rouillard et al. 2020a), whilst both NO-releasing chitosan and alginate were shown to disrupt the mucus and reduce the viscosity and elasticity of sputum by degrading of the mucin and DNA networks (Reighard et al. 2017; Ahonen et al. 2019b). As the thick mucus layers in CF, PCD and COPD greatly contribute to the chronic infection and restrict the diffusion of NO (Hall et al. 2019), and the high viscoelasticity of biofilms may impede pathogen clearance from the lungs and impair antibiotic action (Gloag et al. 2018; Rozenbaum et al. 2019), the application of NOreleasing alginate and chitosan may significantly benefit the treatment of pathogens by both breaking the shield and killing the cells. Despite the need for more investigations, these polymer-based NO donors showed superior efficacies to gaseous NO in biological relevant models and hold great clinical promises.

Polymer NO donors can also be incorporated into indwelling medical devices, such as endotracheal tubes in mechanical 
ventilation, to prevent biofilm formation in the respiratory tract. Fluorinated derivatives of NO donor SNAP, $\mathrm{C}_{2} \mathrm{~F}_{5^{-}}$ SNAP, and $\mathrm{DiCF}_{3} \mathrm{Bn}-\mathrm{SNAP}$, were doped into polyvinylidene fluoride (PVDF) tubes. These tubes showed significant antimicrobial and antibiofilm activities against $S$. aureus and P. aeruginosa (Zhou et al. 2019; Zhou et al. 2018), suggesting a great potential in the development of antibacterial biomedical devices applied in respiratory diseases.

\section{Concluding remarks and future perspectives}

Chronic bacterial infection is the leading cause of morbidity and mortality in CF, COPD and PCD patients, which affect the life quality of millions of people around the world. Bacteria that successfully settle down in the respiratory tracts go through a series of pathoadaptation, including the formation of biofilm aggregates and genetic mutations, granting them high tolerance to many antibiotics (Winstanley et al. 2016). As a result, once chronic infections establish, they are almost untreatable. The insufficient antibiotic suppression may in return induce biofilm formation and the development of resistant genes (Hoffman et al. 2005; Ahmed et al. 2018). Hence, novel antibiofilm therapeutic strategies are urgently needed for the treatment of these patients and minimizing the transmission of superbugs in nosocomial infections.

In the airway, nitric oxide plays a vital role as proinflammatory and immunomodulatory mediator in pathophysiological conditions (Ricciardolo 2003). At high concentrations, it can exhibit bactericidal effect against invading pathogens; at low concentrations, it can revert the established biofilms back to the planktonic state, thus increasing their susceptibility towards antibiotics. Therefore, NO has been regarded as a promising adjunctive therapeutic strategy in chronic lung infections. The functions of NO in vivo heavily rely on the concentrations generated under specific circumstances, the location, and the timing of synthesis. As such, a thorough understanding of NO metabolism in pulmonary disease patients helps to elucidate how the dysfunction of this pathway contributes to chronic infections, and a clear picture of the pathogenesis may significantly facilitate the decision of appropriate NO applications. So far, most of the NO pathway studies in chronic lung infections focused on $\mathrm{CF}$, and supplementation of NO has been shown to improve lung function and help reducing bacterial load. However, the biosynthesis of NO in PCD and COPD patients attracted much less attention, and the lack of knowledge makes it difficult to evaluate the benefit or necessity of different NO augmentation methods. Whilst NO supplementation has been conducted in PCD and COPD, and it was suspected that $\mathrm{NO}$ augmentation will improve treatment of bacterial infections in PCD and COPD, no clinical data is available to demonstrate a significant reduction in bacterial load. On the other hand, solid clinical observations of biofilms were only reported in $\mathrm{CF}$, despite the long-term implications in PCD and COPD patients. The absence of direct observation of biofilms in the lungs or sputa samples from PCD and COPD patients further hinders the development of better strategy for NO-based treatments, when various concentrations of NO perform differently in the inhibition of biofilms in vivo. Future research may focus on (1) NO production and dysfunction in PCD and COPD patients in order to determine whether and how exogenous NO application would benefit these patients; and (2) clarifying the predominant bacterial lifestyle (planktonic or biofilm) and the primary location of pathogens in the respiratory tract (on epithelium or mucus) in PCD and COPD patients so that we can design better NO treatment strategy targeting different formats of bacterial growth without triggering toxic effects on the delicate tissues. The abundant literature of NO pathway and pathogenesis, as well as different detection methods of biofilms and bacterial load in $\mathrm{CF}$, will shed light on similar studies in PCD and COPD patients.

Given that externally applied NO would significantly reduce bacteria in these patients, either based on its antibacterial effect at high concentrations, or antibiofilm function at low scales, the optimised design of NO delivery is crucial for successful applications. Numerous novel synthetic NO donors or polymer NO hybrid drugs have been developed in recent years, and they are primarily tested in vitro. Therefore, the selection of in vitro model greatly affects the precision of conclusion in drug development. Most chemists use type strains and routine culture medium to test their compounds, which do not take into considerations of the plasticity of clinical strains and the complicated in vivo environment. As it is now confirmed that most $P$. aeruginosa aggregates are embedded in the thick mucus layer in CF patients, some recent studies started to test novel compounds in artificial CF sputum medium and yielded some exciting results for bacteria clearance (Ahonen et al. 2019a; Rouillard et al. 2020b). We believe this experiment model may better recapitulate the performance of these drugs in vivo, as $P$. aeruginosa aggregates grown in artificial sputum mimic those isolated from patients to a large extent both physiologically and transcriptionally (Turner et al. 2015; Fung et al. 2010). As such, these NO donors that passed the tests in mucus show great potentials in future clinical trials. The only application of NO donor on biofilms in PCD was conducted in NTHi/epithelium coculture (Walker et al. 2017). Whether this model is suitable to reflect the efficiency of NO drug remains unclear due to the lack of evidence of biofilm existence in vivo. Again, a clear picture of how bacteria are settled in PCD and COPD is crucial for optimised NO donor design, and future NO donor research from the chemistry side should carefully consider the selection of an appropriate in vitro system based on clinical and biological findings. Nevertheless, with so much exciting progress in the discovery of novel NO donors, especially those that specifically release NO with bacterial triggers and from small- 
sized nanoparticles, future NO applications in chronic lung infection diseases may possess a significantly higher precision and efficiency with much fewer side effects.

Acknowledgement The authors would like to thank Prof. Peng George Wang and Prof. Martin Feelisch for insightful discussions in the chemistry of NO donors and their potentials in medical applications, as well as Dr. Catherine Bryant for scrutinising the grammar.

Author contribution Y.M.C. conducted literature search and drafted the manuscript. Y.D.Z. and L.Y. contributed to the conception and design of the manuscript and revised the manuscript. All authors approved the final version.

\section{Declarations}

Ethical statement This article does not contain any studies with human participants or animals performed by any of the authors.

Conflict of interest The authors declare no competing interests.

Open Access This article is licensed under a Creative Commons Attribution 4.0 International License, which permits use, sharing, adaptation, distribution and reproduction in any medium or format, as long as you give appropriate credit to the original author(s) and the source, provide a link to the Creative Commons licence, and indicate if changes were made. The images or other third party material in this article are included in the article's Creative Commons licence, unless indicated otherwise in a credit line to the material. If material is not included in the article's Creative Commons licence and your intended use is not permitted by statutory regulation or exceeds the permitted use, you will need to obtain permission directly from the copyright holder. To view a copy of this licence, visit http://creativecommons.org/licenses/by/4.0/.

\section{References}

Abbas HA, Elsherbini AM, Shaldam MA (2019) Glyceryl trinitrate blocks staphyloxanthin and biofilm formation in Staphylococcus aureus. Afr Health Sci 19(1):1376-1384

Aguirre G, Boiani M, Cerecetto H, Fernández M, González M, León E, Pintos C, Raymondo S, Arredondo C, Pacheco JP, Basombrío MA (2006) Furoxan derivatives as cytotoxic agents: preliminary in vivo antitumoral activity studies. Pharmazie. 61(1):54-59

Ahmad Z, Sharma S, Khuller GK (2005) Inhalable alginate nanoparticles as antitubercular drug carriers against experimental tuberculosis. Int J Antimicrob Agents 26(4):298-303

Ahmed MN, Porse A, Sommer MOA, Høiby N, Ciofu O (2018) Evolution of antibiotic resistance in biofilm and planktonic Pseudomonas aeruginosa populations exposed to subinhibitory levels of ciprofloxacin. Antimicrob Agents Chemother 62(8): e00320-e00318

Ahonen MJR, Suchyta DJ, Zhu H, Schoenfisch MH (2018) Nitric oxidereleasing alginates. Biomacromolecules. 19(4):1189-1197. https:// doi.org/10.1021/acs.biomac. 8 b00063

Ahonen MJR, Dorrier JM, Schoenfisch MH (2019a) Antibiofilm efficacy of nitric oxide-releasing alginates against cystic fibrosis bacterial pathogens. ACS Infect Dis 5(8):1327-1335

Ahonen MJR, Hill DB, Schoenfisch MH (2019b) Nitric oxide-releasing alginates as mucolytic agents. ACS Biomater Sci Eng 5(7):34093418
Alanin MC, Nielsen KG, von Buchwald C, Skov M, Aanaes K, Høiby N, Johansen HK (2015) A longitudinal study of lung bacterial pathogens in patients with primary ciliary dyskinesia. Clin Microbiol Infect 21(12):1093.e1-1093.e7

Allan RN, Morgan S, Brito-Mutunayagam S, Skipp AP, Feelisch M, Hayes SM, Hellier W, Clarke SC, Stoodley P, Burgess A, IsmailKoch H, Salib RJ, Webb JS, Faust SN, Hall-Stoodley L (2016) Low concentrations of nitric oxide modulate Streptococcus pneumoniae biofilm metabolism and antibiotic tolerance. Antimicrob Agents Chemother 60(4):2456-2466

Al-Sa'doni H, Ferro A (2000) S-Nitrosothiols: a class of nitric oxidedonor drugs. Clin Sci (Lond) 98(5):507-520

Annich GM, Meinhardt JP, Mowery KA, Ashton BA, Merz SI, Hirschl RB, Meyerhoff ME, Bartlett RH (2000) Reduced platelet activation and thrombosis in extracorporeal circuits coated with nitric oxide release polymers. Crit Care Med 28(4):915-920

Ansarin K, Chatkin JM, Ferreira IM, Gutierrez CA, Zamel N, Chapman KR (2001) Exhaled nitric oxide in chronic obstructive pulmonary disease: Relationship to pulmonary function. Eur Respir J 157(3 Pt 1):998-1002

Arora DP, Hossain S, Xu Y, Boon EM (2015) Nitric oxide regulation of bacterial biofilms. Biochemistry 54(24):3717-3728

Ashutosh K, Phadke K, Jackson JF, Steele D (2000) Use of nitric oxide inhalation in chronic obstructive pulmonary disease. Thorax. 55(2): $109-113$

Asmawi MZ, Moilanen E, Annala K, Rahkonen P, Kankaanranta H (1999) Effects of nitric oxide donors GEA 3162 and SIN-1 on ethanol-induced gastric ulceration in rats. Eur J Pharmacol 378(1): 123-127

Azimi S, Roberts AEL, Peng S, Weitz JS, McNally A, Brown SP, Diggle SP (2020) Allelic polymorphism shapes community function in evolving Pseudomonas aeruginosa populations. ISME J 14:19291942

Bandarage UK, Chen L, Fang X, Garvey DS, Glavin A, Janero DR, Letts LG, Mercer GJ, Saha JK, Schroeder JD, Shumway MJ, Tam SW (2000) Nitrosothiol esters of diclofenac: synthesis and pharmacological characterization as gastrointestinal-sparing prodrugs. J Med Chem 43(21):4005-4016

Barnes RJ, Bandi RR, Wong WS, Barraud N, McDougald D, Fane A, Kjelleberg S, Rice SA (2013) Optimal dosing regimen of nitric oxide donor compounds for the reduction of Pseudomonas aeruginosa biofilm and isolates from wastewater membranes. Biofouling. 29:203-212

Barnes RJ, Low JH, Bandi RR, Tay M, Chua F, Aung T, Fane AG, Kjelleberg S, Rice SA (2015) Nitric oxide treatment for the control of reverse osmosis membrane biofouling. Appl Environ Microbiol $81: 2515-2524$

Barraud N, Hassett DJ, Hwang S-H, Rice SA, Kjelleberg S, Webb JS (2006) Involvement of nitric oxide in biofilm dispersal of Pseudomonas aeruginosa. J Bacteriol 188:7344-7353

Barraud N, Schleheck D, Klebensberger J, Webb JS, Hassett DJ, Rice SA, Kjelleberg S (2009a) Nitric oxide signaling in Pseudomonas aeruginosa biofilms mediates phosphodiesterase activity, decreased cyclic di-GMP levels, and enhanced dispersal. J Bacteriol 191: $7333-7342$

Barraud N, Storey MV, Moore ZP, Webb JS, Rice SA, Kjelleberg S (2009b) Nitric oxide-mediated dispersal in single- and multispecies biofilms of clinically and industrially relevant microorganisms. Microb Biotechnol 2:370-378

Barraud N, Kardak BG, Yepuri NR, Howlin RP, Webb JS, Faust SN, Kjelleberg S, Rice SA, Kelso MJ (2012) Cephalosporin-3'diazeniumdiolates: targeted NO-donor prodrugs for dispersing bacterial biofilms. Angew Chem Int Ed 51:9057-9060

Barraud N, Kelso MJ, Rice SA, Kjelleberg S (2015) Nitric oxide: a key mediator of biofilm dispersal with applications in infectious diseases. Curr Pharm Des 21(1):31-42 
Bartley BL, Gardner KJ, Spina S, Hurley BP, Campeau D, Berra L, Yonker LM, Carroll RW (2020) High-dose inhaled nitric oxide as adjunct therapy in cystic fibrosis targeting Burkholderia multivorans. Case Rep Pediatr 2020:1536714

Beasley V, Joshi PV, Singanayagam A, Molyneaux PL, Johnston SL, Mallia P (2012) Lung microbiology and exacerbations in COPD. Int J COPD 7:555-569

Bertinaria M, Galli U, Sorba G, Fruttero R, Gasco A, Brenciaglia MI, Scaltrito MM, Dubini F (2003) Synthesis and anti-Helicobacter pylori properties of NO-donor/metronidazole hybrids and related compounds. Drug Dev Res 60:225-239

Bjarnsholt T (2013) The role of bacterial biofilms in chronic infections. APMIS. 136:1-51

Bjarnsholt T, Jensen PØ, Fiandaca MJ, Pedersen J, Hansen CR, Andersen CB, Pressler T, Givskov M, Høiby N (2009) Pseudomonas aeruginosa biofilms in the respiratory tract of cystic fibrosis patients. Pediatr Pulmonol 44:547-558

Bjarnsholt T, Alhede M, Alhede M, Eickhardt-Sørensen SR, Moser C, Kühl M, Jensen PØ, Høiby N (2013) The in vivo biofilm. Trends Microbiol 21(9):466-474

Boyton RJ, Openshaw PJ (2002) Pulmonary defences to acute respiratory infection. Br Med Bull 61(1):1-12

Brindicci C, Ito K, Resta O, Pride NB, Barnes PJ, Kharitonov SA (2005) Exhaled nitric oxide from lung periphery is increased in COPD. Eur Respir J 26(1):52-59

Brindicci C, Kharitonov SA, Ito M, Elliott MW, Hogg JC, Barnes PJ, Ito $\mathrm{K}$ (2010) Nitric oxide synthase isoenzyme expression and activity in peripheral lung tissue of patients with chronic obstructive pulmonary disease. Am J Respir Crit Care Med 181(1):21-30

Brooks CD, Stewart AO, Basha A, Bhatia P, Ratajczyk JD, Martin JG, Craig RA, Kolasa T, Bouska JB, Lanni C (1995) (R)-(+)-N-[3-[5[(4-fluorophenyl)methyl]-2-thienyl]-1-methyl-2-propynyl]-N-hydroxyurea (ABT-761), a second-generation 5-lipoxygenase inhibitor. J Med Chem 38:4768-4775

Burney S, Caulfield JL, Niles JC, Wishnok JS, Tannenbaum SR (1999) The chemistry of DNA damage from nitric oxide and peroxynitrite. Mutat Res 424(1-2):37-49

Cai YM, Webb JS (2020) Optimization of nitric oxide donors for investigating biofilm dispersal response in Pseudomonas aeruginosa clinical isolates. Appl Microbiol Biotechnol 104(20):8859-8869

Cairns S, Thomas JG, Hooper SJ, Wise MP, Frost PJ, Wilson MJ, Lewis MAO, Williams DW (2011) Molecular analysis of microbial communities in endotracheal tube biofilms. PLoS One 6(3):e14759

Carlson HK, Vance RE, Marletta MA (2010) H-NOX regulation of c-diGMP metabolism and biofilm formation in Legionella pneumophila. Mol Microbiol 77:930-942

Chen C, Zhang E (2013) $\beta$-galactosyl-pyrrolidinyl diazeniumdiolate: an efficient tool to investigate nitric oxide functions on promoting cell death. Appl Microbiol Biotechnol 97:7377-7385

Chen C, Shi YQ, Song J, Qi QS, Gu L, Wang PG (2006) Delivery of nitric oxide released from beta-Gal-NONOate activation by betagalactosidase and its activity against Escherichia coli. Biol Pharm Bull 29(6):1239-1241

Chmiel JF, Davis PB (2003) State of the art: Why do the lungs of patients with cystic fibrosis become infected and why can't they clear the infection? Respir Res 4(1):8

Chung KH, Park SM, Baek IC, Jang J, Hong YW, Ahn SW (2016) Cyanide toxicity during cardiopulmonary bypass with small dose of nitroprusside - a case report. Korean J Anesthesiol 69(2):181184

Ciofu O, Tolker-Nielsen T (2019) Tolerance and resistance of Pseudomonas aeruginosa biofilms to antimicrobial agents-how P. aeruginosa can escape antibiotics. Front Microbiol 10:913

Clark ST, Guttman DS, Hwang DM (2018) Diversification of Pseudomonas aeruginosa within the cystic fibrosis lung and its effects on antibiotic resistance. FEMS Microbiol Lett 365(6)
Clini E, Bianchi L, Pagani M, Ambrosino N (1998) Endogenous nitric oxide in patients with stable COPD: correlates with severity of disease. Thorax. 53(10):881-883

Collins SA, Kelso MJ, Rineh A, Yepuri NR, Coles J, Jackson CL, Halladay GD, Walker WT, Webb JS, Hall-Stoodley L, Connett GJ, Feelisch M, Faust SN, Lucas JSA, Allan RN (2017) Cephalosporin-3'-diazeniumdiolate NO donor prodrug PYRROC3D enhances azithromycin susceptibility of nontypeable Haemophilus influenzae biofilms. Antimicrob Agents Chemother 61(2):e02086-e02016

Corradi M, Majori M, Cacciani GC, Consigli GF, De'Munari E, Pesci A (1999) Increased exhaled nitric oxide in patients with stable chronic obstructive pulmonary disease. Thorax. 54(7):572-575

Csoma Z, Bush A, Wilson NM, Donnelly L, Balint B, Barnes PJ, Kharitonov SA (2003) Nitric oxide metabolites are not reduced in exhaled breath condensate of patients with primary ciliary dyskinesia. Chest. 124(2):633-638

Cutruzzolà F, Frankenberg-Dinkel N (2016) Origin and impact of nitric oxide in Pseudomonas aeruginosa biofilms. J Bacteriol 198(1):5565

Daiber A, Münzel T (2015) Organic nitrate therapy, nitrate tolerance, and nitrate-induced endothelial dysfunction: emphasis on redox biology and oxidative stress. Antioxid Redox Signal 23(11):899-942

Darling KE, Evans TJ (2003) Effects of nitric oxide on Pseudomonas aeruginosa infection of epithelial cells from a human respiratory cell line derived from a patient with cystic fibrosis. Infect Immun 71: 2341-2349

Davidson D, Barefield ES, Kattwinkel J, Dudell G, Damask M, Straube R, Rhines J, Chang CT (1998) Inhaled nitric oxide for the early treatment of persistent pulmonary hypertension of the term newborn: a randomized, double-masked, placebo-controlled, doseresponse multicenter study. The I-NO/PPHN Study Group. Pediatrics 101:325-334

Davies DW, Kadar D, Steward DJ, Munro IR (1975) A sudden death associated with the use of sodium nitroprusside for induction of hypotension during anaesthesia. Can Anaesth Soc J 22(5):547-552

de Jesús Valle MJ, Dinis-Oliveira RJ, Carvalho F, Bastos ML, Sánchez Navarro A (2008) Toxicological evaluation of lactose and chitosan delivered by inhalation. J Biomater Sci Polym Ed 19(3):387-397

De Oliveira CPMS, Simplicio FI, De Lima VMR, Yuahasi K, Lopasso FP, Alves VAF, Abdalla DSP, Carrilho FJ, Laurindo FRM, De Oliveira MG (2006) Oral administration of S-nitroso-Nacretylcysteine prevents the onset of non alcoholic fatty liver disease in rats. World J Gastroenterol 12(12):1905-1911

de Souza PC, Fernandes GFS, Marino LB, Ribeiro CM, da Silva PB, Chorilli M, Silva CSP, Resende FA, Solcia MC, de Grandis RA, Costa CAS, Cho SH, Wang Y, Franzblau SG, dos Santos JL, Pavan FR (2020) Furoxan derivatives demonstrated in vivo efficacy by reducing Mycobacterium tuberculosis to undetectable levels in a mouse model of infection. Biomed Pharmacother 130:110592

den Uil CA, Brugts JJ (2015) Impact of intravenous nitroglycerin in the management of acute decompensated heart failure. Curr Heart Fail Rep 12(1):87-93

Deppisch C, Herrmann G, Graepler-Mainka U, Wirtz H, Heyder S, Engel C, Marschal M, Miller CC, Riethmüller J (2016) Gaseous nitric oxide to treat antibiotic resistant bacterial and fungal lung infections in patients with cystic fibrosis: a phase I clinical study. Infection. 44(4):513-520

Derelanko MJ, Gad SC, Powers WJ, Mulder S, Gavigan F, Babich PC (1985) Toxicity of cyclohexanone oxime: I. Hematotoxicity following subacute exposure in rats. Toxicol Sci 5(1):117-127

Diaconu O, Siriopol I, Poloșanu LI, Grigoraș I (2018) Endotracheal tube biofilm and its impact on the pathogenesis of ventilator-associated pneumonia. J Crit Care Med 4(2):50-55 
Dorken G, Ferguson GP, French CE, Poon WCK (2012) Aggregation by depletion attraction in cultures of bacteria producing exopolysaccharide. J R Soc Interface 9(77):3490-3502

dos Santos Fernandes GF, de Souza PC, Marino LB, Chegaev K, Guglielmo S, Lazzarato L, Fruttero R, Chung MC, Pavan FR, dos Santos JL (2016) Synthesis and biological activity of furoxan derivatives against Mycobacterium tuberculosis. Eur J Med Chem 123: 523-531

Downey DG, Bell SC, Elborn JS (2009) Neutrophils in cystic fibrosis. Thorax. 397(6):485-496

Duan J, Kasper DL (2011) Oxidative depolymerization of polysaccharides by reactive oxygen/nitrogen species. Glycobiology. 21(4): 401-409

Duong HTT, Adnan NNM, Barraud N, Basuki JS, Kutty SK, Jung K, Kumar N, Davis TP, Boyer C (2014a) Functional gold nanoparticles for the storage and controlled release of nitric oxide: applications in biofilm dispersal and intracellular delivery. J Mater Chem B 2: 5003-5011

Duong HTT, Jung K, Kutty SK, Agustina S, Adnan NNM, Basuki JS, Kumar N, Davis TP, Barraud N, Boyer C (2014b) Nanoparticle (star polymer) delivery of nitric oxide effectively negates Pseudomonas aeruginosa biofilm formation. Biomacromolecules. 15(7):25832589

Duong-Quy S (2019) Clinical utility of the exhaled nitric oxide (NO) measurement with portable devices in the management of allergic airway inflammation and asthma. J Asthma Allergy 12:331-341

Eichholzer M, Gutzwiller F (1998) Dietary nitrates, nitrites, and N-nitroso compounds and cancer risk: a review of the epidemiologic evidence. Nutr Rev 56(4 Pt 1):95-105

Elmedal B, Mulvany MJ, Simonsen U (2005) Dual impact of a nitric oxide donor, GEA 3175, in human pulmonary smooth muscle. Eur J Pharmacol 516(1):78-84

Elphick HE, Demoncheaux EA, Ritson S, Higenbottam TW, Everard ML (2001) Exhaled nitric oxide is reduced in infants with cystic fibrosis. Thorax 56:151-152

Feelisch M, Schönafingeri K, Noack H (1992) Thiol-mediated generation of nitric oxide accounts for the vasodilator action of furoxans. Biochem Pharmacol 44(6):1149-1157

Feit CG, Chug MK, Brisbois EJ (2019) Development of S-Nitroso- Nacetylpenicillamine impregnated medical grade polyvinyl chloride for antimicrobial medical device interfaces. ACS Appl Bio Mater 2(10):4335-4345

Fiorucci S, Antonelli E, Burgaud JL, Morelli A (2001) Nitric oxidereleasing NSAIDs: a review of their current status. Drug Saf 24(11):801-811

Fischer JT, Hossain S, Boon EM (2019) NosP modulates cyclic-di-gmp signaling in Legionella pneumophila. Biochemistry. 58(42):43254334

Flemming H-C, Wingender J (2010) The biofilm matrix. Nat Rev Microbiol 8:623-633

Fliegauf M, Sonnen AFP, Kremer B, Henneke P (2013) Mucociliary clearance defects in a murine in vitro model of Pneumococcal airway infection. PLoS One 8(3):e59925

Fukada J, Schena S, Tack I, Ruiz P, Kurimoto Y, Pang M, Aitouche A, Abe T, Striker LJ, Pham SM (2000) FK409, a spontaneous nitric oxide releaser, attenuates allograft vasculopathy in a rat aortic transplant model. Circ Res 87(1):66-72

Fung C, Naughton S, Turnbull L, Tingpej P, Rose B, Arthur J, Hu H, Harmer C, Harbour C, Hassett DJ, Whitchurch CB, Manos J (2010) Gene expression of Pseudomonas aeruginosa in a mucin-containing synthetic growth medium mimicking cystic fibrosis lung sputum. J Med Microbiol 59(Pt 9):1089-1100

Ghigo D, Calvino R, Heller R, Calvino R, Alessio P, Fruttero R, Gasco A, Bosia A, Pescarmona G (1992) Characterization of a new compound, S35b, as a guanylate cyclase activator in human platelets. Biochem Pharmacol 43(6):1281-1288
Gifford AM, Chalmers JD (2014) The role of neutrophils in cystic fibrosis. Curr Opin Hematol 21(1):16-22

Gloag ES, German GK, Stoodley P (2018) Viscoelastic properties of Pseudomonas aeruginosa variant biofilms. Sci Rep 8:9691

Glover RE, Corbett JT, Burka LT, Mason RP (1999) In vivo production of nitric oxide after administration of cyclohexanone oxime. Chem Res Toxicol 12(10):952-957

Gordon Sahuquillo M, Geffner P, Aroca M, Villarreal Tello E, Ruiz Ramos J, Ruiz Orenga B, Sanchez Lopez M, Frasquet J, Gonzalez Barbera E, Castellanos Ortega A, Ramirez Galleymore P (2015) Impact of persistent endotracheal tube biofilm on ventilatorassociated pneumonia clinical and microbiological response. Intensive Care Med Exp 3(Suppl 1):A700

Gotoh H, Kasaraneni N, Devineni N, Dallo SF, Weitao T (2010) SOS involvement in stress-inducible biofilm formation. Biofouling. 26(5):603-611

Grasemann H, Michler E, Wallot M, Ratjen F (1997) Decreased concentration of exhaled nitric oxide (NO) in patients with cystic fibrosis. Pediatr Pulmonol 24(3):173-177

Grasemann H, Ioannidis I, Tomkiewicz RP, De Groot H, Rubin BK, Ratjen F (1998) Nitric oxide metabolites in cystic fibrosis lung disease. Arch Dis Child 78(1):49-53

Grasemann H, Gärtig SS, Wiesemann HG, Teschler H, Konietzko N, Ratjen F (1999) Effect of L-arginine infusion on airway NO in cystic fibrosis and primary ciliary dyskinesia syndrome. Eur Respir J 13(1):114-118

Grasemann H, Knauer N, Buscher R, Hubner K, Drazen JM, Ratjen F (2000) Airway nitric oxide levels in cystic fibrosis patients are related to a polymorphism in the neuronal nitric oxide synthase gene. Am J Respir Crit Care Med 162:2172-2176

Grasemann H, Storm van's Gravesande K, Gärtig S, Kirsch M, Büscher R, Drazen JM, Ratjen F (2002) Nasal nitric oxide levels in cystic fibrosis patients are associated with a neuronal NO synthase (NOS1) gene polymorphism. Nitric Oxide Biol Chem 6(2):236-241

Guo FH, De Raeve HR, Rice TW, Stuehr DJ, Thunnissen FBJM, Erzurum SC (1995) Continuous nitric oxide synthesis by inducible nitric oxide synthase in normal human airway epithelium in vivo. Proc Natl Acad Sci U S A 92(17):7809-7813

Hajian B, De Backer J, Vos W, Van Holsbeke C, Ferreira F, Quinn DA, Hufkens A, Claes R, de Backer W (2016) Pulmonary vascular effects of pulsed inhaled nitric oxide in COPD patients with pulmonary hypertension. Int J COPD 11:1533-1541

Hall JR, Maloney SE, Jin H, Taylor JB, Schoenfisch MH (2019) Nitric oxide diffusion through cystic fibrosis-relevant media and lung tissue. RSC Adv 9:40176-40183

Hall JR, Rouillard KR, Suchyta DJ, Brown MD, Ahonen MJR, Schoenfisc MH (2020) Mode of nitric oxide delivery affects antibacterial action. ACS Biomater Sci Eng 6(1):433-441

Hallman M, Bry K (1996) Nitric oxide and lung surfactant. Semin Perinatol 20(3):173-185

Hasan S, Albayaty YNS, Thierry B, Prestidge CA, Thomas N (2018) Mechanistic studies of the antibiofilm activity and synergy with antibiotics of isosorbide mononitrate. Eur J Pharm Sci 115:50-56

Hecker M, Vorhoff W, Bara AT, Mordvintcev PI, Busse R (1995) Characterization of furoxans as a new class of tolerance-resistant nitrovasodilators. Naunyn Schmiedeberg's Arch Pharmacol 351(4): 426-432

Hetrick EM, Shin JH, Paul HS, Schoenfisch MH (2009) Anti-biofilm efficacy of nitric oxide-releasing silica nanoparticles. Biomaterials. 30(14):2782-2789

Hink U, Daiber A, Kayhan N, Kraatz C, Trischler J, Oelze M, Mollnau H, Wenzel P, Vahl C, Münzel T (2007) Oxidative inhibition of the mitochondrial aldehyde dehydrogenase (ALDH-2) promotes nitroglycerin tolerance in human blood vessels. Thorac Cardiovasc Surg 50(23):2226-2232 
Hoegger MJ, Fischer AJ, McMenimen JD, Ostedgaard LS, Tucker AJ, Awadalla MA, Moninger TO, Michalski AS, Hoffman EA, Zabner J, Stoltz DA, Welsh MJ (2014) Impaired mucus detachment disrupts mucociliary transport in a piglet model of cystic fibrosis. Science. 345(6198):818-822

Hoffman LR, D'Argenio DA, MacCoss MJ, Zhang Z, Jones RA, Miller SI (2005) Aminoglycoside antibiotics induce bacterial biofilm formation. Nature. 436(7054):1171-1175

Högman M, Thornadtsson A, Bröms K, Janson C, Lisspers K, Ställberg B, Hedenström H, Malinovschi A (2019) Different relationships between FENO and COPD characteristics in smokers and exsmokers. COPD J Chronic Obstr Pulm Dis 16(3-4):227-233

Hoiby N (1977) Pseudomonas aeruginosa infection in cystic fibrosis. Diagnostic and prognostic significance of Pseudomonas aeruginosa precipitins determined by means of crossed immunoelectrophoresis. A survey. Acta Pathol Microbiol Scand Suppl 58(2):65-79

Høiby N (2002) Understanding bacterial biofilms in patients with cystic fibrosis: Current and innovative approaches to potential therapies. J Cyst Fibros 1(4):249-254

Høiby N (2017) A short history of microbial biofilms and biofilm infections. APMIS. 125(4):272-275

Horani A, Ferkol TW, Dutcher SK, Brody SL (2016) Genetics and biology of primary ciliary dyskinesia. Paediatr Respir Rev 18:18-24

Horváth I, Loukides S, Wodehouse T, Csiszér E, Cole PJ, Kharitonov SA, Barnes PJ (2003) Comparison of exhaled and nasal nitric oxide and exhaled carbon monoxide levels in bronchiectatic patients with and without primary ciliary dyskinesia. Thorax. 58(1):68-72

Hottinger DG, Beebe DS, Kozhimannil T, Prielipp RC, Belani KG (2014) Sodium nitroprusside in 2014: a clinical concepts review. J Anaesthesiol Clin Pharmacol 30(4):462-471

Howlin RP, Cathie K, Hall-stoodley L, Cornelius V, Duignan C, Allan RN, Fernandez BO, Barraud N, Bruce KD, Jefferies J, Kelso M, Kjelleberg S, Rice SA, Rogers GB, Pink S, Smith C, Sukhtankar PS, Salib R, Legg J, Carroll M, Daniels T, Feelisch M, Stoodley P, Clarke SC, Connett G, Faust SN, Webb JS (2017) Low-dose nitric oxide as targeted anti-biofilm adjunctive therapy to treat chronic Pseudomonas aeruginosa infection in cystic fibrosis. Mol Ther 25: 2104-2116

Hoyt JC, Robbins RA, Habib M, Springall DR, Buttery LDK, Polak JM, Barnes PJ (2003) Cigarette smoke decreases inducible nitric oxide synthase in lung epithelial cells. Exp Lung Res 29(1):17-28

Hsu MF, Chen YS, Huang LJ, Tsao LT, Kuo SC, Wang JP (2006) GEA3162, a nitric oxide-releasing agent, activates non-storeoperated $\mathrm{Ca} 2+$ entry and inhibits store-operated $\mathrm{Ca} 2+$ entry pathways in neutrophils through thiol oxidation. Eur J Pharmacol 535(13):43-52

Hunt BC, Stanford D, Xu X, Li J, Gaggar A, Rowe SM, Raju SV, Swords WE (2020) Haemophilus influenzae persists in biofilm communities in a smoke-exposed ferret model of COPD. ERJ Open Res 6(3): 00200-02020

Hynes G, Brightling C, Bafadhel M (2015) Fractional exhaled nitric oxide in chronic obstructive pulmonary disease. Eur Respir J 46: PA3993

Islam M, Durie I, Ramadan R, Purchase D, Marvasi M (2020) Exploitation of nitric oxide donors to control bacterial adhesion on ready-to-eat vegetables and dispersal of pathogenic biofilm from polypropylene. J Sci Food Agric 100(7):3078-3086

Jansen A, Drazen JM, Osborne JA, Brown R, Loscalzo J, Stamler JS (1992) The relaxant properties in guinea pig airways of Snitrosothiols. J Pharmacol Exp Ther 261(1):154-160

Jardeleza C, Foreman A, Baker L, Paramasivan S, Field J, Tan LW, Wormald P-J (2011) The effects of nitric oxide on Staphylococcus aureus biofilm growth and its implications in chronic rhinosinusitis. Int Forum Allergy Rhinol 1:438-444

Jardeleza C, Rao S, Thierry B, Gajjar P, Vreugde S, Prestidge CA, Wormald PJ (2014) Liposome-encapsulated ISMN: a novel nitric oxide-based therapeutic agent against Staphylococcus aureus biofilms. PLoS One 9(3):e92117

Jean D, Maître B, Tankovic J, Meignan M, Adnot S, Brun-Buisson C, Harf A, Delclaux C (2002) Beneficial effects of nitric oxide inhalation on pulmonary bacterial clearance. Crit Care Med 30(2):442447

Ji Y, Li G, Zhang W, Ma D, Xue W (2017) Cross-linked branched polyethylenimine used as a nitric oxide donor for prolonged nitric oxide release. Mater Sci Eng C 81(1):492-499

Jiang WT, Liu XS, Xu YJ, Ni W, Chen SX (2015) Expression of nitric oxide synthase isoenzyme in lung tissue of smokers with and without chronic obstructive pulmonary disease. Chin Med J 128(12): 1584-1589

Jones KL, Hegab AH, Hillman BC, Simpson KL, Jinkins PA, Grisham MB, Owens MW, Sato E, Robbins RA (2000) Elevation of nitrotyrosine and nitrate concentrations in cystic fibrosis sputum. Pediatr Pulmonol 30(2):79-85

Julián E, Baelo A, Gavaldà J, Torrents E (2015) Methyl-hydroxylamine as an efficacious antibacterial agent that targets the ribonucleotide reductase enzyme. PLoS One 10(3):e0122049

Kankaanranta H, Rydell E, Petersson AS, Holm P, Moilanen E, Corell T, Karup G, Vuorinen P, Pedersen SB, Wennmalm Å, Metsä-Ketelä T (1996) Nitric oxide-donating properties of mesoionic 3-aryl substituted oxatriazole-5-imine derivatives. Br J Pharmacol 117(3): 401-406

Kaplan JB (2010) Biofilm dispersal: mechanisms, clinical implications, and potential therapeutic uses. J Dent Res 89(3):205-218

Karup G, Preikschat H, Wilhelmsen ES, Pedersen SB, Marcinkiewicz E, Cieslik K, Gryglewski RJ (1994) Mesoionic oxatriazole derivatives - a new group of NO-donors. Pol J Pharmacol 46(6): $541-552$

Keen C, Gustafsson P, Lindblad A, Wennergren G, Olin AC (2010) Low levels of exhaled nitric oxide are associated with impaired lung function in cystic fibrosis. Pediatr Pulmonol 45(3):241-248

Kelly J (2017) Environmental scan of cystic fibrosis research worldwide. J Cyst Fibros 16(3):367-370

Kido Y, Mitani A, Isago H, Takeshima H, Narumoto O, Tanaka G, Yamauchi Y, Takai D, Ohishi N, Nagase T (2017) Successful treatment of pulmonary injury after nitrogen oxide exposure with corticosteroid therapy: a case report and review of the literature. Respir Med Case Rep 20:107-110

Kishikawa H, Ebberyd A, Römling U, Brauner A, Lüthje P, Lundberg JO, Weitzberg E (2013) Control of pathogen growth and biofilm formation using a urinary catheter that releases antimicrobial nitrogen oxides. Free Radic Biol Med 65:1257-1264

Kolpen M, Bjarnsholt T, Moser C, Hansen CR, Rickelt LF, Kühl M, Hempel C, Pressler T, Høiby N, Jensen PO (2014) Nitric oxide production by polymorphonuclear leucocytes in infected cystic fibrosis sputum consumes oxygen. Clin Exp Immunol 177(1):310 319

Korde Choudhari S, Chaudhary M, Bagde S, Gadbail AR, Joshi V (2013) Nitric oxide and cancer: a review. World J Surg Oncol 11:118

Korten I, Liechti M, Singer F, Hafen G, Rochat I, Anagnostopoulou P, Müller-Suter D, Usemann J, Moeller A, Frey U, Latzin P, Casaulta C (2018) Lower exhaled nitric oxide in infants with cystic fibrosis compared to healthy controls. J Cyst Fibros 17(1):105-108

Kwon L, Rosendorff C (2018) Chapter 20 - The medical treatment of stable angina. in: de Lemos JA, Omland TBT - Chronic coronary artery disease (eds). ISBN 9780323428804. Elsevier. pp 280-302

Lane C, Knight D, Burgess S, Franklin P, Horak F, Legg J, Moeller A, Stick S (2004) Epithelial inducible nitric oxide synthase activity is the major determinant of nitric oxide concentration in exhaled breath. Thorax. 59(9):757-760

Laursen BE, Stankevicius E, Pilegaard H, Mulvany M, Simonsen U (2006) Potential protective properties of a stable, slow-releasing 
nitric oxide donor, GEA 3175, in the lung. Cardiovasc Drug Rev 24(3-4):247-260

Laval J, Ralhan A, Hartl D (2016) Neutrophils in cystic fibrosis. Biol Chem 397(6):485-496

Lee KY, Mooney DJ (2012) Alginate: properties and biomedical applications. Prog Polym Sci 37(1):106-126

Lee J, Kwak D, Kim H, Kim J, Hlaing SP, Hasan N, Cao J, Yoo JW (2020) Nitric oxide-releasing S-nitrosoglutathione-conjugated poly(Lactic-co-glycolic acid) nanoparticles for the treatment of MRSA-infected cutaneous wounds. Pharmaceutics. 12(7):618

Leid JG (2009) Bacterial biofilms resist key host defenses. Microbe. 4(2): 66-70

Li XH, Lee JH (2017) Antibiofilm agents: a new perspective for antimicrobial strategy. J Microbiol 55:753-766

Li Y, Heine S, Entian M, Sauer K, Frankenberg-Dinkel N (2013) NOinduced biofilm dispersion in Pseudomonas aeruginosa is mediated by an MHYT domain-coupled phosphodiesterase. J Bacteriol 195: 3531-3542

Li H, Song C, Liu D, Ai Q, Yu J (2015) Molecular analysis of biofilms on the surface of neonatal endotracheal tubes based on 16S rRNA PCRDGGE and species-specific PCR. Int J Clin Exp Med 8(7):1107511084

Li B, Ming Y, Liu Y, Xing H, Fu R, Li Z, Ni R, Li L, Duan D, Xu J, Li C, Xiang M, Song H, Chen J (2020) Recent developments in pharmacological effect, mechanism and application prospect of diazeniumdiolates. Front Pharmacol 11:923

Liu N, Xu Y, Hossain S, Huang N, Coursolle D, Gralnick JA, Boon EM (2012) Nitric oxide regulation of cyclic di-GMP synthesis and hydrolysis in Shewanella woodyi. Biochemistry. 51:2087-2099

Liu S, Zheng H, Yu W, Ramakrishnan V, Shah S, Gonzalez LF, Singh I, Graffagnino C, Feng W (2020) Investigation of S-nitrosoglutathione in stroke: a systematic review and meta-analysis of literature in preclinical and clinical research. Exp Neurol 328:113262

López A, Martinson SA (2017) Respiratory system, mediastinum, and pleurae. in: Pathologic basis of veterinary disease expert consult. 471-560

Loukides S, Kharitonov S, Wodehouse T, Cole PJ, Barnes PJ (1998) Effect of arginine on mucociliary function in primary ciliary dyskinesia. Lancet. 352(9125):371-372

Lu Z, Huang W, Wang L, Xu N, Ding Q, Cao C (2018) Exhaled nitric oxide in patients with chronic obstructive pulmonary disease: a systematic review and meta-analysis. Int J COPD 13:2695-2705

Lucas JS, Walker WT (2013) Nasal nitric oxide is an important test in the diagnostic pathway for primary ciliary dyskinesia. Ann Am Thorac Soc 10(6):645-647

Lundberg JO (2005) Acute purulent sinusitis triggered by topical nasal nitric oxide synthase inhibition. Am J Respir Crit Care Med 172(4): 512-513

Maestrelli P, Páska C, Saetta M, Turato G, Nowicki Y, Monti S, Formichi B, Miniati M, Fabbri LM (2003) Decreased haem oxygenase-1 and increased inducible nitric oxide synthase in the lung of severe COPD patients. Eur Respir J 21(6):971-976

Maitz MF (2015) Applications of synthetic polymers in clinical medicine. Biosurf Biotribol 1(3):161-176

Major TA, Panmanee W, Mortensen JE, Gray LD, Hoglen N, Hassett DJ (2010) Sodium nitrite-mediated killing of the major cystic fibrosis pathogens Pseudomonas aeruginosa, Staphylococcus aureus, and Burkholderia cepacia under anaerobic planktonic and biofilm conditions. Antimicrob Agents Chemother 54(11):4671-4677

Malerba M, Radaeli A, Olivini A, Damiani G, Ragnoli B, Montuschi P, Ricciardolo FLM (2014) Exhaled nitric oxide as a biomarker in COPD and related comorbidities. Biomed Res Int 2014:271918

Malinovschi A, Janson C, Holmkvist T, Norbäck D, Meriläinen P, Högman M (2006) Effect of smoking on exhaled nitric oxide and flow-independent nitric oxide exchange parameters. Eur Respir J 28(2):339-345
Malo-Ranta U, Ylä-Herttuala S, Metsä-Ketelä T, Jaakkola O, Moilanen E, Vuorinen P, Nikkari T (1994) Nitric oxide donor GEA 3162 inhibits endothelial cell-mediated oxidation of low density lipoprotein. FEBS Lett 337(2):179-183

Mangalea MR, Plumley BA, Borlee BR (2017) Nitrate sensing and metabolism inhibit biofilm formation in the opportunistic pathogen Burkholderia pseudomallei by reducing the intracellular concentration of c-di-GMP. Front Microbiol 8:1353

Maragos CM, Morley D, Wink DA, Dunams TM, Saavedra JE, Hoffman A, Bove AA, Isaac L, Hrabie JA, Keefer LK (1991) Complexes of .NO with nucleophiles as agents for the controlled biological release of nitric oxide. Vasorelaxant effects. J Med Chem 34(11):3242 3247

Martorana PA, Kettenbach B, Bohn H, Schönafinger K, Henning R (1994) Antiischemic effects of pirsidomine, a new nitric oxide donor. Eur J Pharmacol 257(3):267-273

Marvasi M, Chen C, Carrazana M, Durie IA, Teplitski M (2014) Systematic analysis of the ability of nitric oxide donors to dislodge biofilms formed by Salmonella enterica and Escherichia coli O157: H7. AMB Express 4:42

Marvasi M, Durie IA, Henríquez T, Satkute A, Matuszewska M, Prado RC (2016) Dispersal of human and plant pathogens biofilms via nitric oxide donors at $4{ }^{\circ} \mathrm{C}$. AMB Express 6(1):49

Marvig RL, Johansen HK, Molin S, Jelsbak L (2013) Genome analysis of a transmissible lineage of Pseudomonas aeruginosa reveals pathoadaptive mutations and distinct evolutionary paths of hypermutators. PLoS Genet 9(9):e1003741

Matsui H, Wagner VE, Hill DB, Schwab UE, Rogers TD, Button B, Taylor RM, Superfine R, Rubinstein M, Iglewski BH, Boucher RC (2006) A physical linkage between cystic fibrosis airway surface dehydration and Pseudomonas aeruginosa biofilms. Proc Natl Acad Sci U S A 103(48):18131-18136

Maziak W, Loukides S, Culpitt S, Sullivan P, Kharitonov SA, Barnes PJ (1998) Exhaled nitric oxide in chronic obstructive pulmonary disease. Am J Respir Crit Care Med 157:998-1002

Medana C, Di Stilo A, Visentin S, Fruttero R, Gasco A, Ghigo D, Bosia A (1999) NO donor and biological properties of different benzofuroxans. Pharm Res 16(6):956-960

Megson IL, Greig IR, Gray GA, Webb DJ, Butler AR (1997) Prolonged effect of a novel S-nitrosated glyco-amino acid in endotheliumdenuded rat femoral arteries: potential as a slow release nitric oxide donor drug. Br J Pharmacol 122(8):1617-1624

Meng QH, Springall DR, Bishop AE, Morgan K, Evans TJ, Habib S, Gruenert DC, Gyi KM, Hodson ME, Yacoub MH, Polak JM (1998) Lack of inducible nitric oxide synthase in bronchial epithelium: a possible mechanism of susceptibility to infection in cystic fibrosis. J Pathol 184(3):323-331

Mfuh AM, Larionov OV (2015) Heterocyclic N-oxides - an emerging class of therapeutic agents. Curr Med Chem 22(24):2819-2857

Miller MR, Megson IL (2007) Recent developments in nitric oxide donor drugs. British Journal of Pharmacology 151:305-321

Miller MR, Roseberry MJ, Mazzei FA, Butler AR, Webb DJ, Megson IL (2000) Novel S-nitrosothiols do not engender vascular tolerance and remain effective in glyceryltrinitrate-tolerant rat femoral arteries. Eur J Pharmacol 403(1-2):111-119

Miret-Casals L, Baelo A, Julián E, Astola J, Lobo-Ruiz A, Albericio F, Torrents E (2018) Hydroxylamine derivatives as a new paradigm in the search of antibacterial agents. ACS Omega 3(12):17057-17069

Miskoff JA, Dewan A, Chaudhri M (2019) Fractional exhaled nitric oxide testing: Diagnostic utility in asthma, chronic obstructive pulmonary disease, or asthma-chronic obstructive pulmonary disease overlap syndrome. Cureus. 11(6):e4864

Mocca B, Yin D, Gao Y, Wang W (2015) Moraxella catarrhalis-produced nitric oxide has dual roles in pathogenicity and clearance of infection in bacterial-host cell co-cultures. Nitric Oxide Biol Chem $51: 52-62$ 
Morgan R, Kohn S, Hwang S-H, Hassett DJ, Sauer K (2006) BdlA, a chemotaxis regulator essential for biofilm dispersion in Pseudomonas aeruginosa. J Bacteriol 188:7335-7343

Mowery KA, Schoenfisch MH, Saavedra JE, Keefer LK, Meyerhoff ME (2000) Preparation and characterization of hydrophobic polymeric films that are thromboresistant via nitric oxide release. Biomaterials. 21(1):9-21

Mu L, Feng SS, Go ML (2000) Study of synthesis and cardiovascular activity of some furoxan derivatives as potential NO-donors. Chem Pharm Bull 48(6):808-816

Murakami S, Bacha EA, Mazmanian GM, Detruit H, Chapelier A, Dartevelle P, Herve P (1997) Effects of various timings and concentrations of inhaled nitric oxide in lung ischemia-reperfusion. The Paris-Sud University Lung Transplantation Group. Am J Respir Crit Care Med 156(2 Pt 1):454-458

Murrell W (1879) Nitro-glycerine as a remedy for angina pectoris. Lancet. 18(5):370-371

Namivandi-Zangeneh R, Sadrearhami Z, Bagheri A, Sauvage-Nguyen M, Ho KKK, Kumar N, Wong EHH, Boyer C (2018) Nitric oxide-loaded antimicrobial polymer for the synergistic eradication of bacterial biofilm. ACS Macro Lett 7(5):592-597

Nelin LD, Potenziano JL (2019) Inhaled nitric oxide for neonates with persistent pulmonary hypertension of the newborn in the CINRGI study: time to treatment response. BMC Pediatr 19(1):17

Nguyen TK, Selvanayagam R, Ho KKK, Chen R, Kutty SK, Rice SA, Kumar N, Barraud N, Duong HTT, Boyer C (2016) Co-delivery of nitric oxide and antibiotic using polymeric nanoparticles. Chem Sci 7(2):1016-1027

Nyolczas N, Dékány M, Muk B, Szabó B (2018) Combination of hydralazine and isosorbide-dinitrate in the treatment of patients with heart failure with reduced ejection fraction. Adv Exp Med Biol 1067:3145

Oh HS, Constancias F, Ramasamy C, Tang PYP, Yee MO, Fane AG, McDougald D, Rice SA (2018) Biofouling control in reverse osmosis by nitric oxide treatment and its impact on the bacterial community. J Membr Sci 550(15):313-321

Paricio L, Neufeld B, Reynolds M (2019) Combined influence of nitric oxide and surface roughness in biofilm reduction across bacteria strains. Biointerphases. 14(2):021004

Patel RP, Yuan S, Kevil CG (2017) Chapter 4 - S-Nitrosothiols and nitric oxide biology, Nitric oxide (3rd edition), Academic Press, pp 45-56,

Petrova OE, Sauer K (2012a) Dispersion by Pseudomonas aeruginosa requires an unusual posttranslational modification of BdlA. Proc Natl Acad Sci 109:16690-16695

Petrova OE, Sauer K (2012b) PAS domain residues and prosthetic group involved in bdladependent dispersion response by Pseudomonas aeruginosa biofilms. J Bacteriol 194:5817-5828

Pifferi M, Bush A, Maggi F, Michelucci A, Ricci V, Conidi ME, Cangiotti AM, Bodini A, Simi P, Macchia P, Bonere AL (2011) Nasal nitric oxide and nitric oxide synthase expression in primary ciliary dyskinesia. Eur Respir J 37(3):572-577

Plate L, Marletta MA (2012) Nitric oxide modulates bacterial biofilm formation through a multicomponent cyclic-di-GMP signaling network. Mol Cell 46:449-460

Poh WH, Barraud N, Guglielmo S, Lazzarato L, Rolando B, Fruttero R, Rice SA (2017) Furoxan nitric oxide donors disperse Pseudomonas aeruginosa biofilms, accelerate growth, and repress pyoverdine production. ACS Chem Biol 12(8):2097-2106

Privett BJ, Deupree SM, Backlund CJ, Rao KS, Johnson CB, Coneski PN, Schoenfisch MH (2010) Synergy of nitric oxide and silver sulfadiazine against gram-negative, gram-positive, and antibioticresistant pathogens. Mol Pharm 7:2289-2296

Quaderi SA, Hurst JR (2018) The unmet global burden of COPD. Glob Heal Epidemiol Genomics 3:e4

Reid JJ (2001) ABT-761 (Abbott). Curr Opin Investig Drugs 2(1):68-71
Reighard KP, Hill DB, Dixon GA, Worley BV, Schoenfisch MH (2015) Disruption and eradication of Pseudomonas aeruginosa biofilms using nitric oxide-releasing chitosan oligosaccharides. Biofouling. 31(9-10): 775-787

Reighard KP, Ehre C, Rushton ZL, Ahonen MJR, Hill DB, Schoenfisch MH (2017) Role of nitric oxide-releasing chitosan oligosaccharides on mucus viscoelasticity. ACS Biomater Sci Eng 3(6):1017-1026

Ren H, Wu J, Colletta A, Meyerhoff ME, Xi C (2016) Efficient eradication of mature Pseudomonas aeruginosa biofilm via controlled delivery of nitric oxide combined with antimicrobial peptide and antibiotics. Front Microbiol 7:1260

Ricciardolo FLM (2003) Multiple roles of nitric oxide in the airways. Thorax. 58(2):175-182

Richardson G, Benjamin N (2002) Potential therapeutic uses for Snitrosothiols. Clin Sci (Lond) 102(1):99-105

Rindone JP, Sloane EP (1992) Cyanide toxicity from sodium nitroprusside: Risks and management. Ann Pharmacother 26:515-519

Rogers DF (2005) Mucociliary dysfunction in COPD: effect of current pharmacotherapeutic options. Pulm Pharmacol Ther 18(1):1-8

Römling U, Galperin MY, Gomelsky M (2013) Cyclic di-GMP: the first 25 years of a universal bacterial second messenger. Microbiol Mol Biol Rev 77:1-52

Rong F, Tang Y, Wang T, Feng T, Song J, Li P, Huang W (2019) Nitric oxide-releasing polymeric materials for antimicrobial applications: a review. Antioxidants. 8(11):556

Rouillard KR, Hill DB, Schoenfisch MH (2020a) Antibiofilm and mucolytic action of nitric oxide delivered via gas or macromolecular donor using in vitro and ex vivo models. J Cyst Fibros 19(6): $1004-1010$

Rouillard KR, Markovetz MR, Bacudio LG, Hill DB, Schoenfisch MH (2020b) Pseudomonas aeruginosa biofilm eradication via nitric oxide-releasing cyclodextrins. ACS Infect Dis 6(7):1940-1950

Rouillard KR, Novak OP, Pistiolis AM, Yang L, Ahonen MJR, Mcdonald RA, Schoenfisch MH (2020c) Exogenous nitric oxide improves antibiotic susceptibility in resistant bacteria. ACS Infect Dis 7(1):23-33

Rozenbaum RT, van der Mei HC, Woudstra W, de Jong ED, Busscher HJ, Sharma PK (2019) Role of viscoelasticity in bacterial killing by antimicrobials in differently grown Pseudomonas aeruginosa biofilms. Antimicrob Agents Chemother 63(4):e01972-e01918

Rutgers SR, Van Der Mark TW, Coers W, Moshage H, Timens W, Kauffman HF, Koëter GH, Postma DS (1999) Markers of nitric oxide metabolism in sputum and exhaled air are not increased in chronic obstructive pulmonary disease. Thorax. 54(7):576-580

Sadrearhami Z, Shafiee FN, Ho KKK, Kumar N, Krasowska M, Blencowe A, Wong EHH, Boyer C (2019) Antibiofilm nitric oxide-releasing polydopamine coatings. ACS Appl Mater Interfaces 11(7):7320-7329

Sáenz De Tejada I, Garvey DS, Schroeder JD, Shelekhin T, Letts LG, Fernández A, Cuevas B, Gabancho S, Martínez V, Angulo J, Trocha M, Marek P, Cuevas P, Tam SW (1999) Design and evaluation of nitrosylated $\alpha$-adrenergic receptor antagonists as potential agents for the treatment of impotence. J Pharmacol Exp Ther 290(1):121-128

Schairer DO, Chouake JS, Nosanchuk JD, Friedman AJ (2012) The potential of nitric oxide releasing therapies as antimicrobial agents. Virulence. 3(3):271-279

Schlag S, Nerz C, Birkenstock TA, Altenberend F, Götz F (2007) Inhibition of Staphylococcal biofilm formation by nitrite. J Bacteriol 189:7911-7919

Schulz E, Tsilimingas N, Rinze R, Reiter B, Wendt M, Oelze M, Woelken-Weckmüller S, Walter U, Reichenspurner H, Meinertz T, Münzel T (2002) Functional and biochemical analysis of endothelial (dys)function and NO/cGMP signaling in human blood vessels with and without nitroglycerin pretreatment. Circulation. 105(10):11701175 
Secor PR, Michaels LA, Ratjen A, Jennings LK, Singh PK (2018) Entropically driven aggregation of bacteria by host polymers promotes antibiotic tolerance in Pseudomonas aeruginosa. Proc Natl Acad Sci 115(42):10780-10785

Seimetz M, Parajuli N, Pichl A, Veit F, Kwapiszewska G, Weisel FC, Milger K, Egemnazarov B, Turowska A, Fuchs B, Nikam S, Roth M, Sydykov A, Medebach T, Klepetko W, Jaksch P, Dumitrascu R, Garn H, Voswinckel R, Kostin S, Seeger W, Schermuly RT, Grimminger F, Ghofrani HA, Weissmann N (2011) Inducible NOS inhibition reverses tobacco-smoke-induced emphysema and pulmonary hypertension in mice. Cell. 147(2):293-305

Shapiro AJ, Josephson M, Rosenfeld M, Yilmaz O, Davis SD, Polineni D, Guadagno E, Leigh MW, Lavergne V (2017) Accuracy of nasal nitric oxide measurement as a diagnostic test for primary ciliary dyskinesia a systematic review and meta-analysis. Ann Am Thorac Soc 14(7):1184-1196

Shvarts GY, Grigor'ev NB, Severina IS, Ryaposova IK, Lapitskaya AS, Volodarskii LB, Tikhonov AY, Kurbnikova IF, Mazhukin DG, Granik VG (1994) Derivatives of 1,2-diazetine-1,2-dioxide: a new class of nitric oxide generators exhibiting vasodilator activity. Pharm Chem J 30(2):357-366

Simet SM, Sisson JH, Pavlik JA, DeVasure JM, Boyer C, Liu X, Kawasaki S, Sharp JG, Rennard SI, Wyatt TA (2010) Long-term cigarette smoke exposure in a mouse model of ciliated epithelial cell function. Am J Respir Cell Mol Biol 43(6):635-640

Singh RJ, Hogg N, Joseph J, Kalyanaraman B (1996) Mechanism of nitric oxide release from S-nitrosothiols. J Biol Chem 271(31): 18596-18603

Sivaloganathan DM, Brynildsen MP (2020) Quantitative modeling extends the antibacterial activity of nitric oxide. Front Physiol 11:330

Smith AW, Green J, Eden CE, Watson ML (1999) Nitric oxide-induced potentiation of the killing of Burkholderia cepacia by reactive oxygen species: implications for cystic fibrosis. J Med Microbiol 48(5): 419-423

Sogo N, Wilkinson IB, MacCallum H, Khan SQ, Strachan FE, Newby DE, Megson IL, Webb DJ (2000) A novel S-nitrosothiol (RIG200) causes prolonged relaxation in dorsal hand veins with damaged endothelium. Clin Pharmacol Ther 68(1):75-81

Sommer LM, Alanin MC, Marvig RL, Nielsen KG, Høiby N, Von Buchwald C, Molin S, Johansen HK (2016) Bacterial evolution in PCD and CF patients follows the same mutational steps. Sci Rep 6: 28732

Sorba G, Medana C, Fruttero R, Cena C, Di Stilo A, Galli U, Gasco A (1997) Water soluble furoxan derivatives as NO prodrugs. J Med Chem 40(4):463-469

Soren O, Rineh A, Silva DG, Cai Y, Howlin RP, Allan RN, Feelisch M, Davies JC, Connett GJ, Faust SN, Kelso MJ, Webb JS (2019) Cephalosporin nitric oxide-donor prodrug DEA-C3D disperses biofilms formed by clinical cystic fibrosis isolates of Pseudomonas aeruginosa. J Antimicrob Chemother 75(1):117-125

Stewart PS (2015) Antimicrobial tolerance in biofilms. Microbiol Spectr 3(3): 10

Stief CG, Holmquist F, Djamilian M, Krah H, Andersson KE, Jonas U (1992) Preliminary results with the nitric oxide donor linsidomine chlorhydrate in the treatment of human erectile dysfunction. J Urol 148(5):1437-1440

Stuesse DC, Giraud GD, Vlessis AA, Starr A, Trunkey DD, Verrier E, Fullerton D (2001) Hemodynamic effects of S-nitrosocysteine, an intravenous regional vasodilator. J Thorac Cardiovasc Surg 122(2): 371-377

Su Y, Han W, Giraldo C, De Li Y, Block ER (1998) Effect of cigarette smoke extract on nitric oxide synthase in pulmonary artery endothelial cells. Am J Respir Cell Mol Biol 19(5):819-825

Sulemankhil I, Ganopolsky JG, Dieni CA, Dan AF, Jones ML, Prakash S (2012) Prevention and treatment of virulent bacterial biofilms with an enzymatic nitric oxide-releasing dressing. Antimicrob Agents Chemother 56:6095-6103

Sun Z, Sun B, Wang X, Wang W, Zhu L (2006) Anti-inflammatory effects of inhaled nitric oxide are optimized at lower oxygen concentration in experimental Klebsiella pneumoniae pneumonia. Inflamm Res 55(10):430-440

Surette MG (2014) The cystic fibrosis lung microbiome. Ann Am Thor Soc 11(Suppl 1):S61-S65

Sydow K, Daiber A, Oelze M, Chen Z, August M, Wendt M, Ullrich V, Mülsch A, Schulz E, Keaney JF, Stamler JS, Münzel T (2004) Central role of mitochondrial aldehyde dehydrogenase and reactive oxygen species in nitroglycerin tolerance and cross-tolerance. J Clin Invest 113(3):482-489

Taylor EL, Rossi AG, Shaw CA, Dal Rio FP, Haslett C, Megson IL (2004) GEA 3162 decomposes to co-generate nitric oxide and superoxide and induces apoptosis in human neutrophils via a peroxynitrite-dependent mechanism. Br J Pharmacol 143(1):179185

Texereau J, Marullo S, Hubert D, Coste J, Dusser DJ, Dall'Ava-Santucci J, Dinh-Xuan AT (2004) Nitric oxide synthase 1 as a potential modifier gene of decline in lung function in patients with cystic fibrosis. Thorax. 59(2):156-158

Thomas SR, Kharitonov SA, Scott SF, Hodson ME, Barnes PJ (2000) Nasal and exhaled nitric oxide is reduced in adult patients with cystic fibrosis and does not correlate with cystic fibrosis genotype. Chest. 117(4):1085-1089

Thompson CM, Tischler AH, Tarnowski DA, Mandel MJ, Visick KL (2019) Nitric oxide inhibits biofilm formation by Vibrio fischeri via the nitric oxide sensor HnoX. Mol Microbiol 111(1):187-203

Truss MC, Becker AJ, Djamilian MH, Stiff CG, Jonas U (1994) Role of the nitric oxide donor linsidomine chlorhydrate (SIN-1) in the diagnosis and treatment of erectile dysfunction. Urology. 44(4):553-556

Tullett JM, Rees DD, Shuker DE, Gescher A (2001) Lack of correlation between the observed stability and pharmacological properties of Snitroso derivatives of glutathione and cysteine-related peptides. Biochem Pharmacol 62(9):1239-1247

Turner KH, Wessel AK, Palmer GC, Murray JL, Whiteley M (2015) Essential genome of Pseudomonas aeruginosa in cystic fibrosis sputum. Proc Natl Acad Sci U S A 112(13):4110-4115

Udeh CI, Ting M, Arango M, Mick S (2015) Delayed presentation of nitroprusside-induced cyanide toxicity. Ann Thorac Surg 99(4): $1432-1434$

Vandecandelaere I, Coenye T (2015) Microbial composition and antibiotic resistance of biofilms recovered from endotracheal tubes of mechanically ventilated patients. Adv Exp Med Biol 830:137-155

Vandecandelaere I, Matthijs N, van Nieuwerburgh F, Deforce D, Vosters P, de Bus L, Nelis HJ, Depuydt P, Coenye T (2012) Assessment of microbial diversity in biofilms recovered from endotracheal tubes using culture dependent and independent approaches. PLoS One 7(6):e38401

Velázquez CA, Chen QH, Citro ML, Keefer LK, Knaus EE (2008) Second-generation aspirin and indomethacin prodrugs possessing an $\mathrm{O}(2)$-(acetoxymethyl)-1-(2-carboxypyrrolidin-1-yl)diazenium-1, 2-diolate nitric oxide donor moiety: design, synthesis, biological evaluation, and nitric oxide release studies. J Med Chem 51(6): 1954-1961

Wainwright CL, Martorana PA (1993) Pirsidomine, a novel nitric oxide donor, suppresses ischemic arrhythmias in anesthetized pigs. J Cardiovasc Pharmacol 22(Suppl 7):S44-S50

Walker WT, Jackson CL, Lackie PM, Hogg C, Lucas JS (2012) Nitric oxide in primary ciliary dyskinesia. Eur Respir J 40(4):1024-1032

Walker WT, Liew A, Harris A, Cole J, Lucas JS (2013) Upper and lower airway nitric oxide levels in primary ciliary dyskinesia, cystic fibrosis and asthma. Respir Med 107(3):380-386

Walker WT, Jackson CL, Allan RN, Collins SA, Kelso MJ, Rineh A, Yepuri NR, Nicholas B, Lau L, Johnston D, Lackie P, Faust SN, 
Lucas JSA, Hall-Stoodley L (2017) Primary ciliary dyskinesia ciliated airway cells show increased susceptibility to Haemophilus influenzae biofilm formation. Eur Respir J 50(3):1700612

Webert KE, McCormack DG, Mehta S, Duggan M, Scott JA, Lewis JF, Vanderzwan J (2000) Effects of inhaled nitric oxide in a rat model of Pseudomonas aeruginosa pneumonia. Crit Care Med 28(7):23972405

Weinberger B, Heck DE, Laskin DL, Laskin JD (1999) Nitric oxide in the lung: therapeutic and cellular mechanisms of action. Pharmacol Ther 84:401-411

Wijers CDM, Chmiel JF, Gaston BM (2017) Bacterial infections in patients with primary ciliary dyskinesia: comparison with cystic fibrosis. Chron Respir Dis 14(4):392-406

Williams DE, Boon EM (2019) Towards understanding the molecular basis of nitric oxide-regulated group behaviors in pathogenic bacteria. J Innate Immun 11:205-215

Winstanley C, O'Brien S, Brockhurst MA (2016) Pseudomonas aeruginosa evolutionary adaptation and diversification in cystic fibrosis chronic lung infections. Trends Microbiol 24(5):327-337

Worlitzsch D, Tarran R, Ulrich M, Schwab U, Cekici A, Meyer KC, Birrer P, Bellon G, Berger J, Weiss T, Botzenhart K, Yankaskas JR, Randell S, Boucher RC, Döring G (2002) Effects of reduced mucus oxygen concentration in airway Pseudomonas infections of cystic fibrosis patients. J Clin Invest 109:317-325

Wright JL, Tai H, Dai J, Churg A (2002) Cigarette smoke induces rapid changes in gene expression in pulmonary arteries. Lab Investig 82(10):1391-1398

Xu W, Zheng S, Dweik RA, Erzurum SC (2006) Role of epithelial nitric oxide in airway viral infection. Free Radic Biol Med 41(1):19-28

Yang L, Feura ES, Ahonen MJR, Schoenfisch MH (2018) Nitric oxidereleasing macromolecular scaffolds for antibacterial applications. Adv Healthc Mater 7(13):e1800155

Yoshida M, Taguchi O, Gabazza EC, Kobayashi T, Yamakami T, Kobayashi H, Maruyama K, Shima T (1997) Combined inhalation of nitric oxide and oxygen in chronic obstructive pulmonary disease. Am J Respir Crit Care Med 155(2):526-529

Zemke AC, Shiva S, Burns JL, Moskowitz SM, Pilewski JM, Gladwin MT, Bomberger JM (2014) Nitrite modulates bacterial antibiotic susceptibility and biofilm formation in association with airway epithelial cells. Free Radic Biol Med 77:307-316

Zemke AC, D'Amico EJ, Snell EC, Torres AM, Kasturiarachi N, Bomberger JM (2020) Dispersal of epithelium-associated Pseudomonas aeruginosa biofilms. mSphere 5(4):e00630-e00620

Zhang JM, Orihashi K, Sueda T, Matsuura Y (2000) Cardioprotective effects of FK409, a nitric oxide donor, after isolated rat heart preservation for 16 hours. Annals of Thoracic Surgery. Ann Thorac Surg 70(5):1601-1606

Zhang X, Wang X, Li H, Wang W, Zhao S (2019a) The value of nasal nitric oxide measurement in the diagnosis of primary ciliary dyskinesia. Pediatr Investig 3:209-213

Zhang Y, Zhao Y, Dong D, Li X, Li Z, Li S, Wang J (2019b) Effects of isosorbide mononitrate loaded nanoparticles conjugated with antiStaphylococcus aureus $\alpha$-toxin on Staphylococcus aureus biofilms. Exp Ther Med 19(2):1267-1274

Zhou Y, Zhang Q, Wu J, Xi C, Meyerhoff ME (2018) Synthesis and characterization of a fluorinated S-nitrosothiol as the nitric oxide donor for fluoropolymer-based biomedical device applications. J Mater Chem B 6:6142-6152

Zhou Y, Tan J, Wu J, Zhang Q, Andre J, Xi C, Chen Z, Meyerhoff ME (2019) Nitric oxide releasing poly(vinylidene fluoride-cohexafluoropropylene)films using a fluorinated nitric oxide donor to greatly decrease chemical leaching. Acta Biomater 90:112-121

Zumft WG (1997) Cell biology and molecular basis of denitrification. Microbiol Mol Biol Rev 61(4):533-616

Publisher's note Springer Nature remains neutral with regard to jurisdictional claims in published maps and institutional affiliations. 